\title{
Functionalized Pyrrolidines Inhibit $\alpha$-Mannosidase Activity and Growth of Human Glioblastoma and Melanoma Cells
}

\author{
Hélène Fiaux,${ }^{\dagger}$ Florence Popowycz,${ }^{\dagger}$ Sylvain Favre,${ }^{\dagger}$ Catherine Schütz ${ }^{\dagger}$ Pierre Vogel,${ }^{\dagger}$ \\ Sandrine Gerber-Lemaire, ${ }^{*}, \dagger$ and Lucienne Juillerat-Jeanneret*, ${ }^{*}$ \\ Institute of Chemical Sciences and Engineering, Swiss Federal Institute of Technology (EPFL), BCH, CH-1015 Lausanne, \\ Switzerland, and University Institute of Pathology, CHUV, Bugnon 25, CH-1011 Lausanne, Switzerland
}

Received December 7, 2004

New substituted pyrrolidine-3,4-diol derivatives were prepared from D-(-)- and L-(+)-phenyl glycinol. The influence of the configuration and the substitution of the lateral side chain of these derivatives on the inhibition of 25 commercial glycosidases were determined. $(2 R, 3 R, 4 S)$ 2-(\{[(1R)-2-Hydroxy-1-phenylethyl]amino $\}$ methyl)pyrrolidine-3,4-diol $((+)-7 \mathbf{a})$ was a potent and selective inhibitor of jack bean $\alpha$-mannosidase $\left(K_{\mathrm{i}}=135 \mathrm{nM}\right)$. However, when evaluated on human tumor cells, $\mathbf{7 a}$, and the reference compound swainsonine, did not efficiently inhibit the growth of glioblastoma cells. Further derivatization of the hydroxyl group with lipophilic groups to increase bioavailability improved their growth inhibitory properties for human glioblastoma and melanoma cells. In particular, the 4-bromobenzoyl derivative $\mathbf{2 6}$ demonstrated high efficacy for human tumor cells whereas primary human fibroblasts were less sensitive to 26. Therefore, functionalized pyrrolidines have the potential to inhibit the growth of tumor cells and display selectivity for tumor cells when compared to normal cells.

\section{Introduction}

Very few therapeutic options exist for the treatment of human glioblastoma and metastatic melanoma, in part because of their resistance to chemotherapeutic agents. ${ }^{1}$ Therefore, new drugs have to be developed that are able to overcome resistance, and such novel approaches may be represented by agents targeting the glycosylation pathways of cancer cells. Aberrant glycosylation of glycoproteins and glycolipids was reported to be one of the molecular changes that accompany malignant transformations. ${ }^{2}$ As both catabolic and processing glycosidases are involved in the transformation of normal cells to cancer cells and in tumor cell invasion and migration, ${ }^{3}$ it has been proposed that the specific inhibition of $\alpha$-mannosidases involved in the addition of $\mathrm{N}$-linked carbohydrates to glycoproteins may provide a new anticancer strategy ${ }^{4-6}$ able to overcome resistance to conventional chemotherapeutic agents. Clinical trials have demonstrated that swainsonine, a natural inhibitor of Golgi $\alpha$-mannosidase II, which contains a 4-amino-4-deoxy-mannofuranoside moiety, ${ }^{7}$ decreases the growth of solid tumors and hematological malignancies. ${ }^{8}$ In particular, Kino and co-workers were the first to report that the subcutaneous administration of swainsonine completely inhibited the growth and the formation of lung metastases of a sarcoma..$^{9}$ Nevertheless, the toxicity observed for this alkaloid as well as the undesired coinhibition of lysosomal fucosidases resulted in the search for new, more selective $\alpha$-mannosidases inhibitors. Some analogues of swainsonine

* Corresponding authors: Dr. Lucienne Juillerat, phone +4121314 7173, fax +41 213147115 , e-mail lucienne.juillerat@chuv.hospvd.ch; Dr. Sandrine Gerber-Lemaire, phone +41 21693 9372, fax +41 21693 9355, e-mail sandrine.gerber@epfl.ch.

$\dagger$ Institute of Chemical Sciences and Engineering, Swiss Federal Institute of Technology.

$\ddagger$ University Institute of Pathology. such as 2 (Chart 1) as well as simpler derivatives have shown interesting inhibitory properties. ${ }^{10-12}$ We previously reported that 3,4-dihydroxy-pyrrolidin-2-yl derivatives such as $\mathbf{3}$ and $\mathbf{4}$ are selective and competitive inhibitors of $\alpha$-mannosidase from the jack bean. ${ }^{13,14}$ Recently, we reported that 2-aminomethyl-5-(hydroxymethyl)pyrrolidine-3,4-diol derivatives of type 4 are competitive inhibitors of $\alpha$-mannosidases with higher potency than the corresponding diamines with no substituent at the $\mathrm{C}(5)$ position of the pyrrolidine ring. ${ }^{15}$ However, the potential of these molecules to inhibit tumor cell growth was not evaluted.

Here we report the synthesis and characterization of new derivatives of the diamine $\mathbf{3 a}$ where a hydroxymethyl substituent was introduced on the lateral side chain of pyrrolidine and was able to inhibit purified glycosidases at low concentration. The effect of these derivatives on the proliferation of human glioblastoma and melanoma cells, two tumors associated with a highproliferative and invasive potential, multiple resistance toward conventional chemotherapeutic agents, and poor prognosis, and on human fibroblasts as models for nontumoral cells was also determined. Drug resistance may result from the expression by tumor cells of enzyme systems able to reverse the cytostatic or cytotoxic effect of these agents or from the expression of efflux pumps able to extrude these agents out of tumor cells. Therefore novel strategies, which must be able to reverse tumor resistance to chemotherapeutic agents, have to be envisioned to treat these cancers. We have previously shown that molecules unrelated to conventional therapeutic agents, such as the drugs targeting the endothelin ${ }^{16,17}$ and the renin-angiotensin ${ }^{18}$ systems, or carbohydrate analogues, ${ }^{19}$ may be of some interest. In this context, agents able to modify the glycosylation pathways of tumor cells may be particularly valuable. 
Chart 1. Swainsonine and Pyrrolidine Derivatives as Inhibitors of $\alpha$-Mannosidases

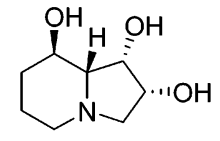

Swainsonine (1)

jack bean : $\mathrm{IC}_{50}=0.4 \mu \mathrm{M}$

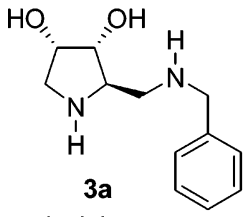

jack bean :

$\mathrm{IC}_{50}=60 \mu \mathrm{M}$ $\mathrm{K}_{\mathrm{i}}=7.4 \mu \mathrm{M}$<smiles>OC[C@@H]1N[C@H](CNCc2ccccc2)[C@H](O)[C@@H]1O</smiles>

jack bean :

$\mathrm{IC}_{50}=6.2 \mu \mathrm{M}$

$\mathrm{K}_{\mathrm{i}}=1.2 \mu \mathrm{M}$

\section{Results and Discussion}

Synthesis. The fully protected carbaldehyde $\mathbf{5}^{20}$ was submitted to a reductive amination procedure in the presence of phenylglycinol derivatives and sodium triacetoxyborohydride for an in situ reduction of the soformed imines (Scheme 1). Acidic treatment of protected derivatives $\mathbf{6}$ afforded diamines $\mathbf{7 a - 7 d}$ with a $40-74 \%$ yield (two steps). The previously reported alcohol $\mathbf{8}^{21}$ was oxidized under Swern conditions and treated as above with $\mathrm{D}-(-)$ - $\alpha$-phenylglycinol to provide diamine 10, bearing two hydroxymethyl groups, with a $65 \%$ yield (three steps).

Functionalization of the primary alcohol of derivative $7 \mathbf{a}$ was also performed in order to investigate the role of this hydroxyl moiety in enzyme recognition. D-(-)- $\alpha-$ phenylglycinol was transformed into diallylamine $\mathbf{1 1}$ with an $85 \%$ yield, allowing protection of the primary alcohol as simple ethers (benzyl and methyl ethers) with good to quantitative yields. Substituted benzyl ethers were also introduced. Palladium promoted cleavage of the allyl moieties in the presence of 2-mercaptobenzoic acid as an allyl scavenger, ${ }^{21}$ followed by a reductive amination procedure with carbaldehyde $\mathbf{5}$, led to diamines 18 and $\mathbf{1 9}$, after quantitative deprotection in acidic medium. Deallylation of the 3-fluorobenzyl ether resulted in a poor yield of the corresponding amine 17, which was then submitted to the same sequence of reductive amination/acidic deprotection to provide the functionalized pyrrolidine $\mathbf{2 0}$ in $40 \%$ yield.

Further derivatives containing lipophilic esters were prepared in order to determine whether modification of the hydroxyl group would improve efficacy (Scheme 2). Moreover, the introduction of lipophilic aromatic moieties should improve cell membrane penetration. D-()- $\alpha$-Phenylglycinol was protected as a tert-butyl carbamate (21), allowing acylation of the primary alcohol with substituted aromatic acyl chlorides. After acidic treatment, the resulting amines were also engaged in a reductive amination procedure with pyrrolidine carbaldehyde 5 to provide compounds $\mathbf{2 3 - 2 6}$ after quantitative cleavage of the Boc and acetonide protecting groups. Intermediate $\mathbf{2 1}$ was also converted into the corresponding azido derivative which was used to introduce amide groups on the lateral side chain of the pyrrolidine such as the substituted benzamide $\mathbf{2 9}$.

Inhibition of Purified Plant Glycosidases. The inhibitory potential of compounds $\mathbf{7 a - 7 d}, \mathbf{1 0}, \mathbf{1 8}-\mathbf{2 0}$, 23-26, and 29 toward 25 commercially available gly$\operatorname{cosidases}^{22}$ was determined and compared with the previously reported pyrrolidine derived inhibitors. The data are summarized in Table 1 . The compounds (at 1 $\mathrm{mM}$ concentration) did not inhibit $\alpha$-L-fucosidases (from bovine epididymis or human placenta), $\alpha$ - and $\beta$-galactosidases (from coffee beans, Aspergillus niger, Aspergillus orizae, Escherichia coli, or jack bean), $\alpha$ - and $\beta$-glucosidases (from yeast, rice, Aspergillus niger, rhizopus mold, almond, or Caldocellum saccharolyticum), $\beta$-mannosidases (from Helix pomatia), $\beta$-xylosidase (from Aspergillus niger), $\alpha-N$-acetylgalactosaminidase, and $\beta$ - $N$-acetylglucosaminidase (from chicken liver) (results not shown). However, $\alpha$-mannosidases from jack bean and almond were inhibited by these derivatives with a high selectivity. In particular, the $\mathrm{D}-(-)-\alpha$-phenylglycinol-substituted derivative $\mathbf{7 a}$ was a potent $\left(K_{\mathrm{i}}=135 \mathrm{nM}\right.$, $\mathrm{IC}_{50}=700 \mathrm{nM}$ ), competitive (as determined on a Lineweaver-Burk plot) inhibitor of jack bean $\alpha$-mannosidase, a reliable model enzyme for mammalian Golgi $\alpha$-mannosidases II, ${ }^{23}$ but was less potent for almond $\alpha$-mannosidase. Introduction of an hydroxymethyl group on the lateral side chain of the pyrrolidine ring led to a considerable increase of the inhibitory potential in comparison with the nonsubstituted derivative $\mathbf{3 a}\left(\mathrm{IC}_{50}\right.$ $=60 \mu \mathrm{M}$ for $\mathbf{3 a} \mathrm{vs} \mathrm{IC}_{50}=700 \mathrm{nM}$ for $\mathbf{7 a}$, factor of increase $=85$ ). Its diastereoisomer $\mathbf{7 b}$ was much less active $\left(\mathrm{IC}_{50}=100 \mu \mathrm{M}\right)$, demonstrating the influence of the stereochemistry of the lateral side chain of the pyrrolidine for optimal recognition by the enzyme. Introduction of a second aromatic group (7c and $\mathbf{7 d}$ ) resulted in a significant decrease of the inhibition of both $\alpha$-mannosidases. The steric hindrance of these derivatives may be too important to allow them to enter the active site of the enzyme.

The free hydroxyl group on the lateral side chain seemed to also be a determinant for inhibition since the introduction of a methyl ether (18) led to a drastic loss of inhibitory activity (77\% and $63 \%$ inhibition at $1 \mathrm{mM}$ for $\alpha$-mannosidases from the jack bean and almond, respectively). The benzyl-protected derivative 19 still presented an inhibition constant of $16 \mu \mathrm{M}\left(\mathrm{IC}_{50}=58\right.$ $\mu \mathrm{M}$ ) toward $\alpha$-mannosidase from jack bean (80 times less active than $\mathbf{7 a}$ ). The ester and amide derivatives 23-26 and 29 were also less active than the parent unprotected compound $\mathbf{7 a}$ with average $\mathrm{IC}_{50}$ values of $60 \mu \mathrm{M}$ and a competitive type of inhibition. This can be explained by an increase of the steric hindrance as well as the loss of potential hydrogen bonding with the active site of the enzyme. Finally, introduction of a second hydroxymethyl group (compound 10) improved the inhibitory potential on $\alpha$-mannosidase from almond $\left(\mathrm{IC}_{50}=3.0 \mu \mathrm{M}, K_{\mathrm{i}}=600 \mathrm{nM}\right)$ when compared with 
Scheme 1. Synthesis of Phenylglycinol Derivatives<smiles>CC1(C)OC2CN(C(=O)OCc3ccccc3)C(CO)C2O1</smiles>

5<smiles>[R]NCC1C2OC(C)(C)OC2CN1C(=O)OCc1ccccc1</smiles>

6

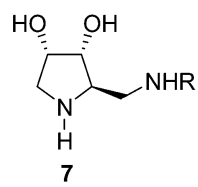<smiles>[R]=CC(CO)C([18OH])[18OH]</smiles>

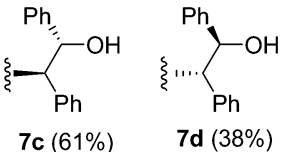

7c $(61 \%) \quad 7 d(38 \%)$

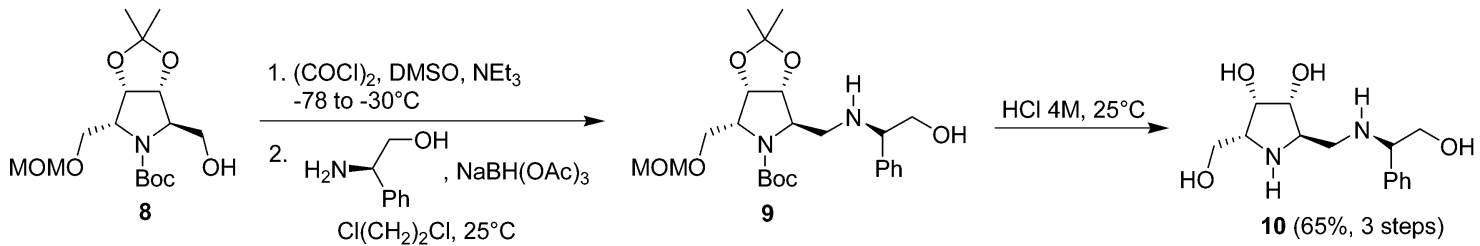
$\mathrm{Cl}\left(\mathrm{CH}_{2}\right)_{2} \mathrm{Cl}, 25^{\circ} \mathrm{C}$

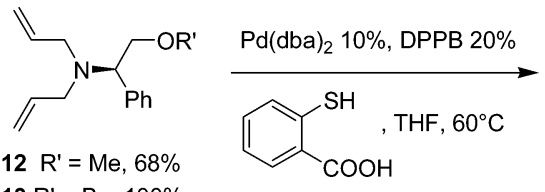
$13 \mathrm{R}^{\prime}=\mathrm{Bn}, 100 \%$
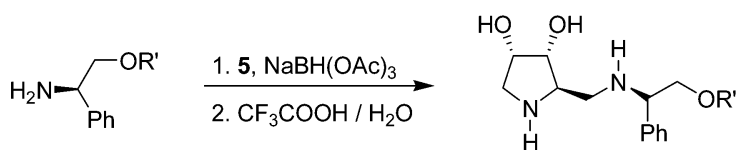

$15 \mathrm{R}^{\prime}=\mathrm{Me}, 100 \%$

$18 \mathrm{R}^{\prime}=\operatorname{Me}(74 \%$, from 12$)$

$16 \mathrm{R}^{\prime}=\mathrm{Bn}, 100 \%$

$17 \mathrm{R}^{\prime}=3$-fluoroBn, $18 \%$

$20 \mathrm{R}^{\prime}=3$-fluoroBn (40\% from 14$)$

Scheme 2. Pyrrolidine Derivatives from Aromatic Phenylglycinol Esters and Amides
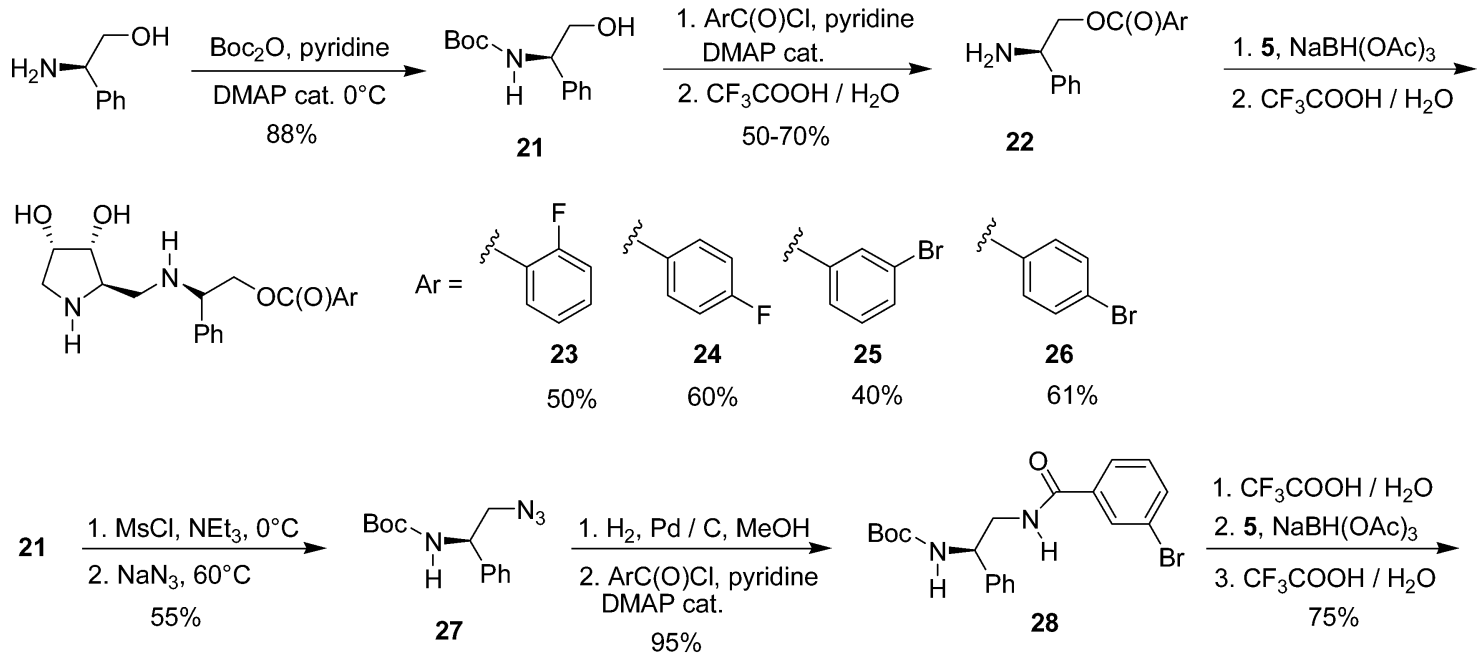<smiles>O=C(NCC(NCC1NC[C@@H](O)[C@@H]1O)c1ccccc1)c1cccc(Br)c1</smiles>

29

compound 7a. Nevertheless, 10 was less active than $\mathbf{7 a}$ on $\alpha$-mannosidase from jack bean $\left(K_{\mathrm{i}}=1.35 \mu \mathrm{M}\right)$.

Evaluation of Functionalized Pyrrolidines in Human Glioblastoma and Melanoma Cells or Fibroblasts. First, the effects of derivatives $\mathbf{3 a}, \mathbf{3 b}, \mathbf{7 a}-$ $\mathbf{7 d}$, and $\mathbf{1 0}$ were determined in human LN18 and
LNZ308 glioblastoma cells using the MTT ((3,4,5dimethylthiazol-yl)-2,5-diphenyl tetrazolium) assay, which determines the number of metabolically active cells present. Derivatives 3a, 7b-7d, and $\mathbf{1 0}$ did not display any activity (results not shown). Compound $\mathbf{3 b}$ at 250 $\mu \mathrm{M}$ induced a $23 \%$ decrease in the number of metaboli- 
Table 1. Inhibitory Activities of Pyrrolidine Derivatives toward $\alpha$-Mannosidases from Jack Bean or Almond

\begin{tabular}{|c|c|c|}
\hline $\begin{array}{l}\text { inhibitor/ } \\
\text { enzyme }\end{array}$ & $\begin{array}{c}\alpha \text {-mannosidase } \\
\text { (jack bean) }\end{array}$ & $\underset{\text { (almond) }}{\alpha-\operatorname{mannosidase}}$ \\
\hline $7 \mathbf{a}$ & $\begin{array}{l}100 \%^{a}(\mathrm{C})^{b} \\
\mathrm{IC}_{50}=700 \mathrm{nM} \\
K_{\mathrm{i}}=135 \mathrm{nM}\end{array}$ & $\begin{array}{l}93 \%(\mathrm{C}) \\
\mathrm{IC}_{50}=46 \mu \mathrm{M} \\
K_{\mathrm{i}}=9.5 \mu \mathrm{M}\end{array}$ \\
\hline $7 \mathbf{b}$ & $\begin{array}{l}92 \% \\
\mathrm{IC}_{50}=100 \mu \mathrm{M}\end{array}$ & $55 \%$ \\
\hline $7 \mathrm{c}$ & $\begin{array}{l}88 \% \\
\mathrm{IC}_{50}=110 \mu \mathrm{M}\end{array}$ & $55 \%$ \\
\hline $7 d$ & $\begin{array}{l}84 \% \\
\mathrm{IC}_{50}=128 \mu \mathrm{M}\end{array}$ & $50 \%$ \\
\hline 10 & $\begin{array}{l}98 \%(\mathrm{C}) \\
\mathrm{IC}_{50}=4.2 \mu \mathrm{M} \\
K_{\mathrm{i}}=1.35 \mu \mathrm{M}\end{array}$ & $\begin{array}{l}96 \%(\mathrm{C}) \\
\mathrm{IC}_{50}=3.0 \mu \mathrm{M} \\
K_{\mathrm{i}}=600 \mathrm{nM}\end{array}$ \\
\hline 18 & $77 \%$ & $63 \%$ \\
\hline 19 & $\begin{array}{l}92 \%(\mathrm{C}) \\
\mathrm{IC}_{50}=58 \mu \mathrm{M} \\
K_{\mathrm{i}}=16 \mu \mathrm{M}\end{array}$ & $75 \%$ \\
\hline 20 & $\begin{array}{l}99 \%(\mathrm{C}) \\
\mathrm{IC}_{50}=30 \mu \mathrm{M} \\
K_{\mathrm{i}}=7 \mu \mathrm{M}\end{array}$ & nd \\
\hline 23 & $\begin{array}{l}83 \%(\mathrm{C}) \\
\mathrm{IC}_{50}=63 \mu \mathrm{M} \\
K_{\mathrm{i}}=24 \mu \mathrm{M}\end{array}$ & nd \\
\hline 24 & $\begin{array}{l}92 \%(\mathrm{C}) \\
\mathrm{IC}_{50}=60 \mu \mathrm{M} \\
K_{\mathrm{i}}=19 \mu \mathrm{M}\end{array}$ & nd \\
\hline 25 & $79 \%$ & nd \\
\hline 26 & $\begin{array}{l}92 \% \\
\mathrm{IC}_{50}=55 \mu \mathrm{M}\end{array}$ & nd \\
\hline 29 & $\begin{array}{l}95 \% \\
\mathrm{IC}_{50}=89 \mu \mathrm{M}\end{array}$ & nd \\
\hline
\end{tabular}

${ }^{a}$ Percent inhibition at $1 \mathrm{mM}$ and optimal $\mathrm{pH} .{ }^{b}$ Competitive inhibition.

cally active cells. We observed some growth inhibitory activity of 7a on LN18 and LNZ308 at high concentration (results not shown); however this compound was unstable under biological conditions, and we did not investigate it in more detail. As the hydrophilic character of these molecules may hinder their transport across a cell membrane, we prepared more lipophilic derivatives and evaluated them on the growth of human glioblastoma cells exposed for 24,48 , or $72 \mathrm{~h}$ to these molecules. These compounds demonstrated a time- and concentration-dependent inhibition of growth, with $\mathbf{2 6}$ being the most rapidly active molecule, producing almost complete inhibition within $24 \mathrm{~h}$. These results are summarized in Table 2.

Swainsonine, an $\alpha$-mannosidase inhibitor with promising antitumoral properties, ${ }^{4,7-9}$ only inhibited by $20 \%$ glioblatoma cell growth at $250 \mu \mathrm{M}$ and was not active at a lower concentration (Figure 1A). Compound 7a, the most active inhibitor for plant $\alpha$-mannosidases, was not active on human glioblastoma cells. These discrepancies could result from a poor cell membrane permeability and a low uptake of these compounds by glioblastoma cells. Among the lipophilic substituents of the lateral side chain of $\mathbf{7 a}$, the 4-bromobenzoyl ester $\mathbf{2 6}$ was the most efficient. The replacement of the bromo by a fluoro (24), or a bromo (25), or a fluoro (23), in position 3 of the aromatic ring resulted in the loss of antiproliferative properties. The use of an amide bond rather than an ester bond to link the bromobenzoyl moiety to the pyrrolidine backbone, resulting in $\mathbf{2 9}$, decreased the efficacy. 4-Bromobenzoïc acid or ethyl 4-bromobenzoate, which may result from the hydrolysis of $\mathbf{2 6}$ by cell
Table 2. Time-course of Growth Inhibition of Glioblastoma Cells $^{a}$ by Functionalized Pyrrolidines

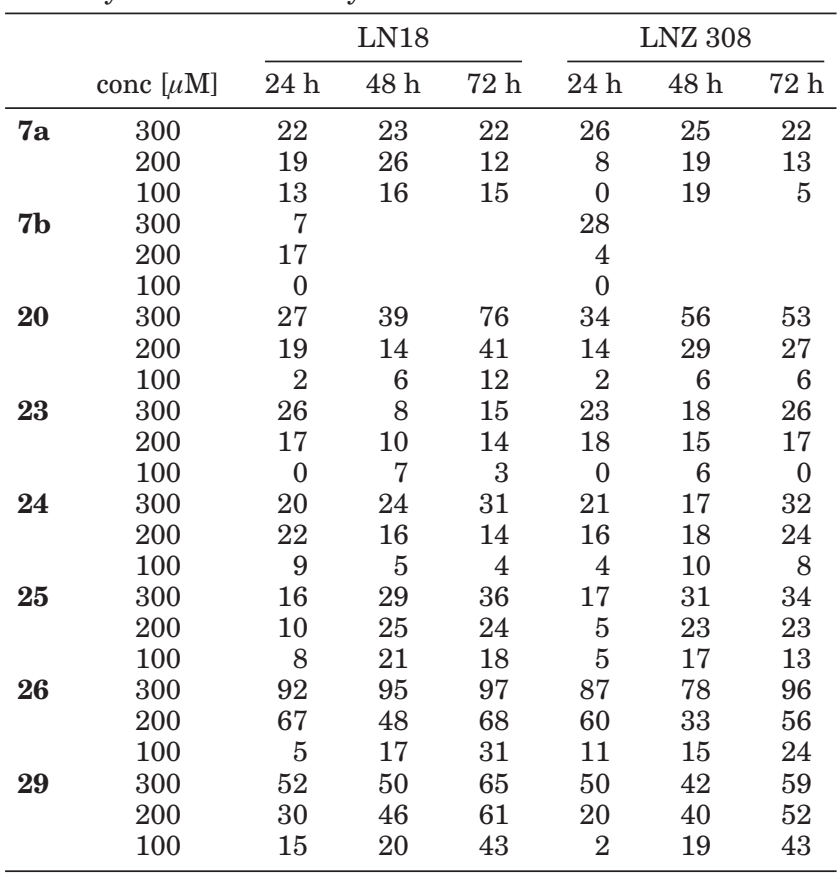

${ }^{a}$ Cells were exposed for 24,48 , or $72 \mathrm{~h}$ to $0,100,200$, or 300 $\mu \mathrm{M}$ of the various synthetic derivatives, then the MTT assay was performed for the last $2 \mathrm{~h}$ of incubation. The percent of residual mitochondrial activity was calculated as the ratio of treated to control cells.

esterases, were without effect on glioblastoma and melanoma cell growth (results not shown) excluding an effect from the aromatic substituent. A dose-response evaluation $(300-100 \mu \mathrm{M})$ of the antiproliferative effects of 26 and 29 (parts B and C of Figure 1) in both glioblastoma cells demonstrated the increased efficacy of $\mathbf{2 6}$ when compared to swainsonine or 29. The $\mathrm{IC}_{50}$ values for 26 and 29 were determined to be 125 and $225 \mu \mathrm{M}$ in LN 18 and LNZ 308 cells, respectively. These results suggest that cellular esterases, rather than peptidases, are able to release the more hydrophilic derivative $\mathbf{7 a}$ with a free terminal alcohol, which was shown to be the most active and selective mannosidases inhibitor of this series of pyrrolidine derivatives.

We then evaluated whether $\mathbf{2 6}$ has the potential to diminish cell growth by inhibiting the synthesis of DNA and/or proteins. The evaluation of the incorporation of $\left[{ }^{3} \mathrm{H}\right]$-thymidine and $\left[{ }^{3} \mathrm{H}\right]$-Leu following $6 \mathrm{~h}$ of exposure of the cells to these molecules demonstrated that $\mathbf{2 6}$ inhibited thymidine incorporation (DNA synthesis) (Figure 2A) at slightly lower concentrations and to a higher extent than inhibiting leucine incorporation (protein synthesis) (Figure 2B). These results suggest that this molecule acts initially by inhibiting DNA synthesis (93\% inhibition at $300 \mu \mathrm{M}$ in LN18), then the rate of protein synthesis will decrease $(82 \%$ at $300 \mu \mathrm{M}$ in LN18), resulting in diminished cell survival.

Table 3 summarizes and compares the effects on cell growth (MTT assay) after $24 \mathrm{~h}$ of exposure to swainsonine, $\mathbf{7 a}$ (the best inhibitor for plant $\alpha$-mannosidases), and 26 in glioblastoma and melanoma, demonstrating the increased efficiency of 26; however it has to be emphasized that relatively high concentrations $(>100$ $\mu \mathrm{M})$ must be applied in order to have complete inhibition 

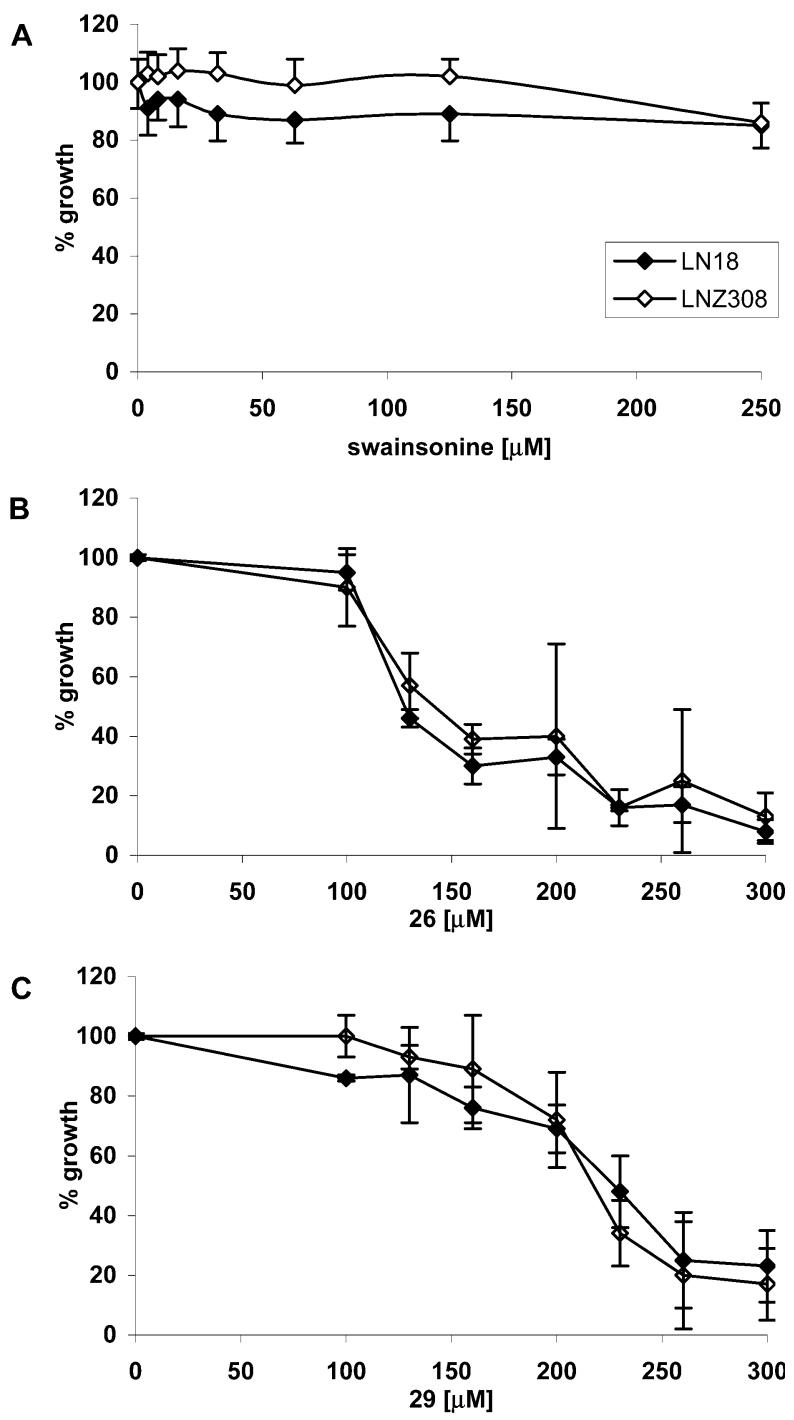

Figure 1. Growth inhibition of human glioblastoma cells by swainsonine, 26, or 29. Cells were exposed for $24 \mathrm{~h}$ to an increasing concentration of either swainsonine (A), 26 (B), or $29(\mathrm{C})$, then the MTT assay was performed for the last $2 \mathrm{~h}$ and the percent of growth was calculated as the ratio of the MTT reduction of treated to untreated cells. Results are shown as means $\pm \mathrm{SD}$ of triplicate wells of one representative experiment out of three.

of cell growth, suggesting that the bioavailability of this series of molecules may be further optimized.

Therefore, $\mathbf{2 6}$ was the most promising derivative of this series in glioblastoma cells. Furthermore, we determined whether this compound was also able to inhibit DNA and protein synthesis and survival in human cancer cells originating from a tumor different from glioblastoma, the melanoma. Exposure of human $\mathrm{Me} 237$ and Me275 melanoma cells for $6 \mathrm{~h}$ to 26 resulted in a blockade of DNA synthesis (Figure 3A) and protein synthesis (Figure 3B), and after $24 \mathrm{~h}$, the number of metabolically active, melanoma cells decreased (Figure $3 \mathrm{C}$ ), as determined using the MTT assay.

Finally, we evaluated the sensitivity of human fibroblasts, as models for nontumoral cells to 26 (Figure 4). Fibroblasts were less sensitive to this compound than glioblastoma and melanoma cells for the inhibition of DNA synthesis after $6 \mathrm{~h}$ of exposure (Figure 4A) or survival after $24 \mathrm{~h}$ of exposure (Figure $4 \mathrm{~B}$ ) suggesting
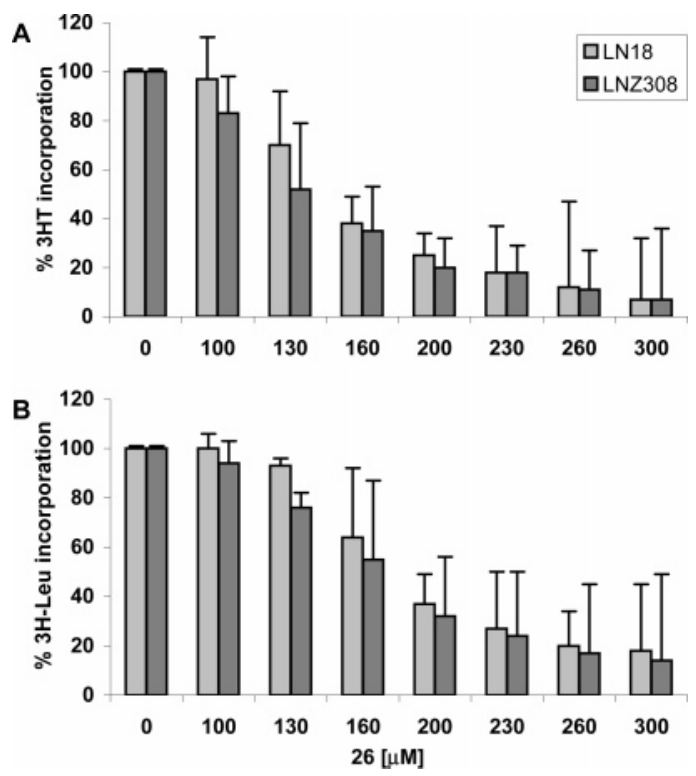

Figure 2. Inhibition of DNA and protein synthesis by $\mathbf{2 6}$ in human glioblastoma cells: light gray bars, LN18 and dark gray bars, LNZ308. Cells were exposed for $6 \mathrm{~h}$ to an increasing concentration of 26. The incorporation of either $(\mathrm{A})$ radioactive thymidine $\left[{ }^{3} \mathrm{HT}\right]$ or (B) radioactive leucine $\left[{ }^{3} \mathrm{H}\right] \mathrm{Leu}$ was performed for the last $2 \mathrm{~h}$. Results are shown as means $\pm \mathrm{SD}$ of triplicate wells of one representative experiment out of three.

Table 3. Comparison of Dose Dependency of Growth Inhibition of Glioblastoma and Melanoma Cells ${ }^{a}$ by Functionalized Pyrrolidines

\begin{tabular}{llccc}
\hline & & $300 \mu \mathrm{M}$ & $200 \mu \mathrm{M}$ & $100 \mu \mathrm{M}$ \\
\hline swainsonine & LN18 & 13 & 18 & 7 \\
& LNZ308 & 16 & 24 & 25 \\
& Me275 & 15 & 22 & 14 \\
compound 7a & Le237 & 20 & 21 & 8 \\
& LN18 & 22 & 19 & 13 \\
& Me275 & 26 & 8 & 0 \\
compound 26 & Me237 & 14 & 16 & 15 \\
& LN18 & 92 & 30 & 16 \\
& LNZ308 & 87 & 67 & 5 \\
& Me275 & 100 & 88 & 11 \\
& Me237 & 100 & 98 & 54 \\
\hline
\end{tabular}

${ }^{a}$ Cells were exposed for $24 \mathrm{~h}$ to either swainsonine, compound $\mathbf{7 a}$, or 26 at $0,100,200$, or $300 \mu \mathrm{M}$, then the MTT assay was performed for the last $2 \mathrm{~h}$ of incubation. The percent of growth inhibition was calculated by comparing treated to untreated cells.

some cell selectivity of $\mathbf{2 6}$ between tumoral and nontumoral cells.

\section{Conclusion}

In conclusion, a series of functionalized pyrrolidine inhibitors of mannosidases have been prepared and evaluated. The phenylglycinol derivative $\mathbf{7 a}$ was shown to be a potent, selective and competitive inhibitor of $\alpha$-mannosidase from the jack bean $\left(K_{\mathrm{i}}=135 \mathrm{nM}\right)$. However, it did not inhibit the growth of human tumor cells. We postulated that its hydrophilic character prevented its internalization by cells. In support of this hypothesis, the more lipophilic derivative $\mathbf{2 6}$ inhibited the growth of human glioblastoma and melanoma cells more than the growth of human fibroblasts and more efficiently than swainsonine, a potential antitumoral agent. The presence of lipophilic substituents increased the efficacy making these derivatives able to inhibit DNA and protein synthesis and tumor cell survival. 

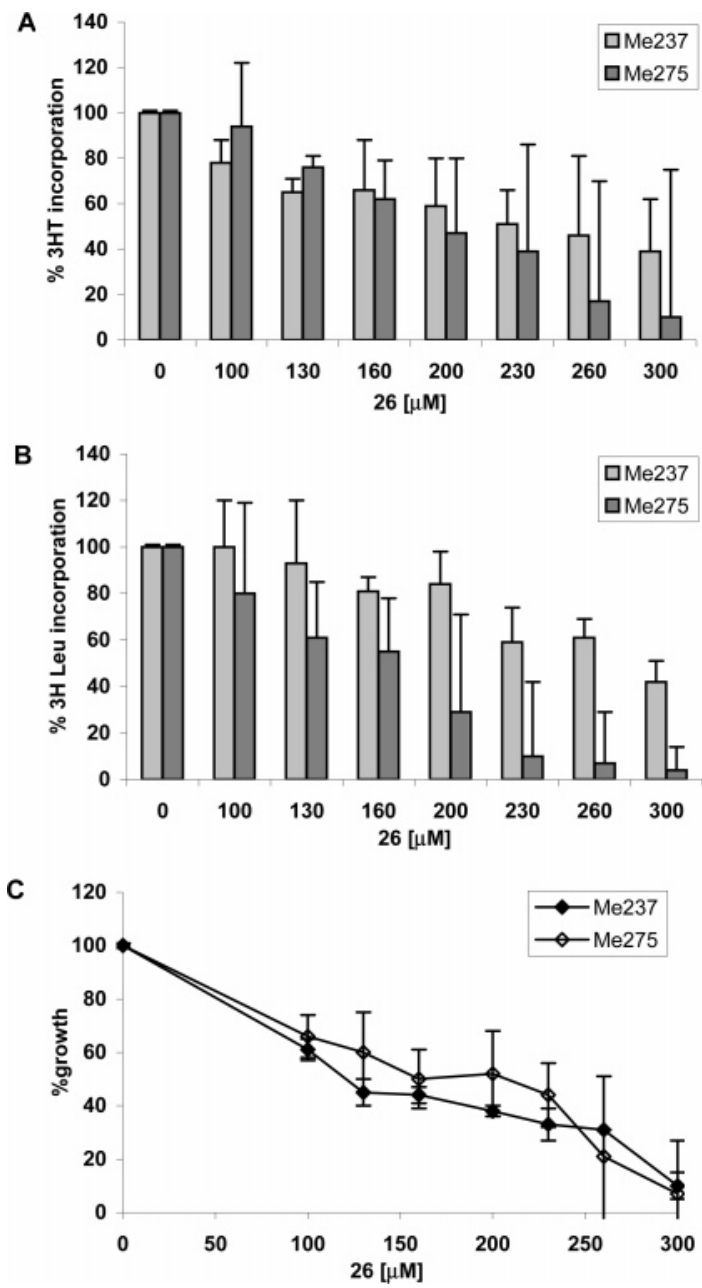

Figure 3. Inhibition of growth and DNA synthesis in human melanoma cells by 26: light gray bars, Me237 and dark gray bars, Me275. Cells were exposed to an increasing concentration of 26, either (A) for $6 \mathrm{~h}$ and the incorporation of radioactive thymidine $\left({ }^{3} \mathrm{HT}\right)$ was performed for the last $2 \mathrm{~h}$ or $(\mathrm{B})$ for 24 $\mathrm{h}$, and the MTT assay was performed for the last $2 \mathrm{~h}$, and the percent of growth was calculated as the ratio of thymidine incorporation or MTT reduction of treated to untreated cells. Results are shown as means \pm SD of triplicate wells of one representative experiment out of three.

Thus the exposure of tumor cells to ester derivatives of prodrugs analogue of $\mathbf{2 6}$ would result in two advantages: the hydrolysis of the ester would release molecules more active on mannosidases than the prodrugs, and the hydrophilic character of the active molecules following its intracellular hydrolysis by esterases would prevent its passive diffusion out of the cells. Such a strategy already proved to be efficient for ester derivatives of aminolevulinic acid in the context of photodynamic therapy protocols. ${ }^{24}$

Therefore, functionalized pyrrolidines represent promising lead agents able to control the progression of human glioblastoma and melanoma, to inhibit DNA and protein synthesis and tumor cell survival, and to display some selectivity for tumor cells compared to nontumoral cells.

\section{Experimental Section}

Chemistry. Commercial reagents (Fluka, Aldrich) were used without purification. Solvents were distilled prior to use: tetrahydrofuran (THF) from $\mathrm{Na}$ and benzophenone, $\mathrm{MeOH}$
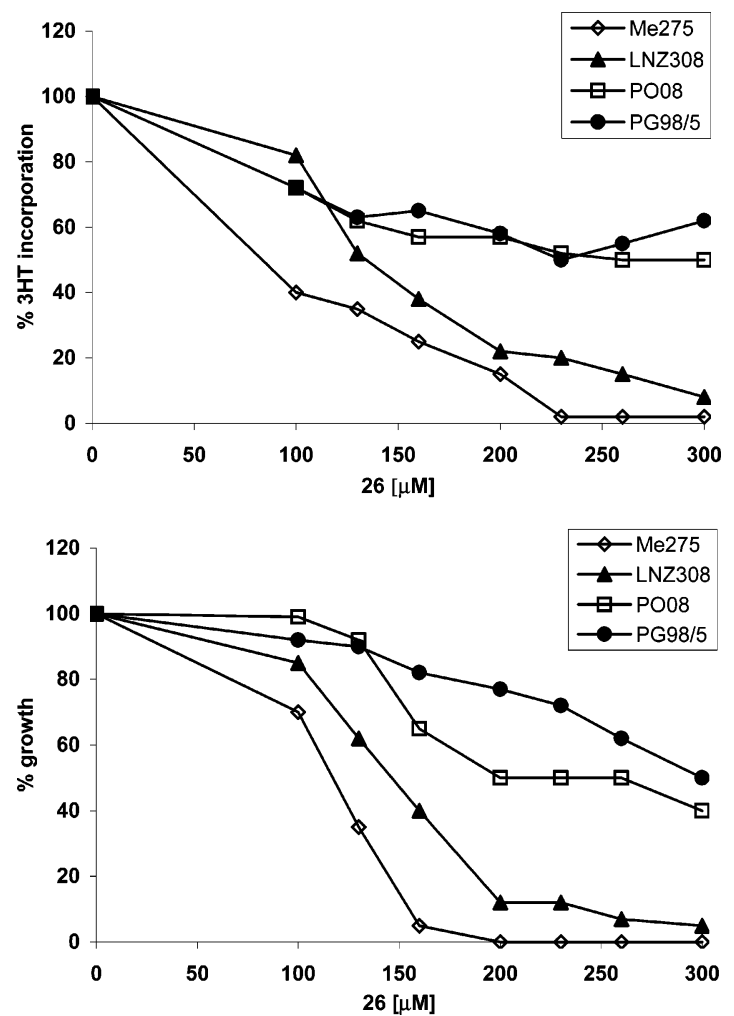

Figure 4. Comparison of the growth inhibition induced by 26 in human primary fibroblasts and human tumor cells. Human fibroblasts (PG98/5 and PO08) or tumor cells (LNZ308 glioblastoma and Me237 melanoma) were exposed to an increasing concentration of $\mathbf{2 6}$, either (A) for $6 \mathrm{~h}$ and the incorporation of radioactive thymidine $\left({ }^{3} \mathrm{HT}\right)$ was performed for the last $2 \mathrm{~h}$ or (B) for $24 \mathrm{~h}$, and the MTT assay was performed for the last $2 \mathrm{~h}$, and the percent of growth was calculated as the ratio of thymidine incorporation or MTT reduction of treated to untreated cells. Results are shown as means $\pm \mathrm{SD}$ of triplicate wells of one representative experiment out of three.

from $\mathrm{Mg}$ and $\mathrm{I}_{2}$, and $\mathrm{CH}_{2} \mathrm{Cl}_{2}$ from $\mathrm{CaH}_{2}$. The light petroleum ether used refers to the fraction boiling at $40-60{ }^{\circ} \mathrm{C}$. Solutions after reactions and extractions were evaporated in a rotatory evaporator under reduced pressure. Liquid/solid flash chromatography (FC): columns of silica gel $(0.040-0.63 \mathrm{~mm}$, Merck No. 9385 silica gel 60, 240-400 mesh). Thin-layer chromatography (TLC) for reaction monitoring: Merck silica gel $60 \mathrm{~F}_{254}$ plates; detection by UV light; Pancaldi reagent $\left(\left(\mathrm{NH}_{4}\right)_{6} \mathrm{MoO}_{4}\right.$, $\left.\mathrm{Ce}\left(\mathrm{SO}_{4}\right)_{2}, \mathrm{H}_{2} \mathrm{SO}_{4}, \mathrm{H}_{2} \mathrm{O}\right)$ or $\mathrm{KMnO}_{4}$. IR spectra: Perkin-Elmer1420 spectrometer. ${ }^{1} \mathrm{H}$ NMR spectra: Bruker-ARX-400 spectrometer $(400 \mathrm{MHz}) ; \delta(\mathrm{H})$ in ppm relative to the solvent's residual ${ }^{1} \mathrm{H}$ signal $\left(\mathrm{CHCl}_{3}, \delta(\mathrm{H}) 7.27 ; \mathrm{CH}_{3} \mathrm{OD}, \delta(\mathrm{H}) 3.34\right)$ as internal reference; all ${ }^{1} \mathrm{H}$ assignments were confirmed by $2 \mathrm{D}$ correlation spectroscopy-45 and 2D-nuclear Overhauser effect spectrometry spectra. ${ }^{13} \mathrm{C}$ NMR spectra: same instrument as above $(101 \mathrm{MHz}) ; \delta(\mathrm{C})$ in ppm relative to solvent's C-signal $\left(\mathrm{CDCl}_{3}, \delta(\mathrm{C}) 77.0 ; \mathrm{CD}_{3} \mathrm{OD}, \delta(\mathrm{C}) 48.5\right)$ as internal reference; coupling constants $J$ in hertz. MS: Nermag R-10-10C, chemical ionization $\left(\mathrm{NH}_{3}\right)$ mode $\mathrm{m} / \mathrm{z}(\mathrm{amu})$ (\% relative base peak $(100 \%))$. Electrospray mass spectra were obtained from the Swiss Institute of Technology Mass Spectral Facility. Elemental analyses: Ilse Beetz, D-96301 Kronach, Germany. Analytical high-performance liquid chromatography (HPLC) was performed on a Waters 600 apparatus, equipped with a Waters absorbance detector set at $214 \mathrm{~nm}$ and $\mathrm{C}_{4}, \mathrm{C}_{8}$, and $\mathrm{C}_{18}$ Grace Vydac columns. Elution was performed using the following gradient over $30 \mathrm{~min}, 100 \%\left(0.9 \% \mathrm{TFA}\right.$ in $\left.\mathrm{H}_{2} \mathrm{O}\right)$ to $100 \%(0.9 \%$ TFA in $\mathrm{MeCN}$ ).

Procedure 1: General Method for the Reductive Aminations. $\mathrm{NaBH}(\mathrm{OAc})_{3}(1.4$ equiv) was added portionwise to a stirred solution of aldehyde RCHO (0.1-0.3 M) and primary 
amine $\mathrm{R}^{\prime} \mathrm{NH}_{2}(0.1-0.3 \mathrm{M})$ in 1,2-dichloroethane at $25^{\circ} \mathrm{C}$. After the complete disappearance of the reagents (TLC monitoring), the solution was poured into a saturated aqueous solution of $\mathrm{NaHCO}_{3}(5 \mathrm{~mL}$ per mmol). The organic layer was collected, and the aqueous layer was extracted with EtOAc $(10 \mathrm{~mL}$ per mmol, 3 times). The combined organic extracts were dried $\left(\mathrm{MgSO}_{4}\right)$. Solvent evaporation in vacuo and flash chromatography on silica gel gave pure diamines.

Procedure 2: General Method for the Acidic Cleavage of Boc and Acetonide Moieties. A 5\% solution of protected diamines in $4: 1 \mathrm{CF}_{3} \mathrm{COOH} / \mathrm{H}_{2} \mathrm{O}$ or in $4 \mathrm{M}$ aqueous $\mathrm{HCl}$ was stirred at $25{ }^{\circ} \mathrm{C}$ for $1 \mathrm{~h}$. After solvent evaporation in vacuo, the residue was purified by flash chromatography on silica gel or alumina.

tert-Butyl $(3 \mathrm{a} R, 4 R, 6 \mathrm{aS})-4-(\{[(1 R)-2-H y d r o x y-1-p h e n y l e t h y l]-$ amino methyl)-2,2-dimethyl tetrahydro-5H-[1,3]dioxolo[4,5-c]pyrrole-5-carboxylate ((-)-6a). Procedure 1: 5 (261 $\mathrm{mg}, 0.96 \mathrm{mmol}), \mathrm{D}-(-)-\alpha-$ phenylglycinol $(132 \mathrm{mg}, 0.96 \mathrm{mmol}$ ), $\mathrm{NaBH}(\mathrm{OAc})_{3}(285 \mathrm{mg}, 1.34 \mathrm{mmol}), \mathrm{ClCH}_{2} \mathrm{CH}_{2} \mathrm{Cl}(10 \mathrm{~mL}) . \mathrm{FC}$ (EtOAc): $281 \mathrm{mg}$ (74\%), 1.2:1 mixture of rotamers. ${ }^{1} \mathrm{H}$ NMR

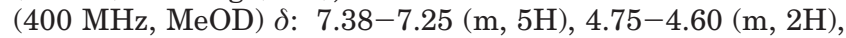
$4.10(\mathrm{dd}, 1 \mathrm{H}), 4.03(\mathrm{dd}, 1 \mathrm{H}), 3.75(\mathrm{~m}, 2 \mathrm{H}), 3.66-3.51(\mathrm{~m}, 2 \mathrm{H})$, $3.37(\mathrm{~m}, 1 \mathrm{H}), 2.64-2.43(\mathrm{~m}, 2 \mathrm{H}), 1.48,1.40(2 \mathrm{~s}, 9 \mathrm{H}), 1.43(\mathrm{~s}$, $3 \mathrm{H}), 1.33(\mathrm{~s}, 3 \mathrm{H}) .{ }^{13} \mathrm{C} \mathrm{NMR}(101 \mathrm{MHz}, \mathrm{MeOD}) \delta: 157.3,154.6$, $142.9,130.4,129.6,129.4,113.4,85.4,84.9,82.2,82.1,81.6$, $80.9,68.9,68.7,67.5,67.2,66.2,65.8,53.9,53.6,50-49,29.5$, 28.1, 25.9. MS (CI- $\left.\mathrm{NH}_{3}\right): 394(16), 393\left(\mathrm{M}+\mathrm{H}^{+}, 12\right), 362(3)$, 338 (12), 305 (15), 262 (6), 199 (10), 142 (42), 118 (100), 91 (95), 77 (26). Anal. $\left(\mathrm{C}_{21} \mathrm{H}_{32} \mathrm{~N}_{2} \mathrm{O}_{5}\right) \mathrm{C} 64.49, \mathrm{H} 8.07$.

$(2 R, 3 R, 4 S)-2-(\{[(1 R)-2-H y d r o x y-1-p h e n y l e t h y l]$ amino $\}-$ methyl)pyrrolidine-3,4-diol $((+)-7 \mathbf{a})$. Procedure $2: \mathbf{6 a}(25$ $\mathrm{mg}), 4 \mathrm{M} \mathrm{HCl}$. FC $\left(\mathrm{CH}_{3} \mathrm{CN} / \mathrm{NH}_{4} \mathrm{OH} 4: 1\right): 16 \mathrm{mg}(100 \%) .{ }^{1} \mathrm{H}$ NMR (400 MHz, MeOD) $\delta: 7.42-7.29$ (m, 5H), 4.26 (ddd, 1H), $3.97(\mathrm{dd}, 1 \mathrm{H}), 3.83(\mathrm{dd}, 1 \mathrm{H}), 3.70(\mathrm{dd}, 1 \mathrm{H}), 3.64(\mathrm{dd}, 1 \mathrm{H}), 3.49-$ $3.43(\mathrm{~d}$ and $\mathrm{m}, 2 \mathrm{H}), 3.25$ (dd, 1H), $2.93(\mathrm{dd}, 1 \mathrm{H}), 2.78$ (dd, 1H). ${ }^{13} \mathrm{C}$ NMR (101 MHz, MeOD) $\delta$ : 142.6, 130.6, 129.6, 129.4, 75.5, $71.9,68.3,67.5,63.7,51.5,48.1) . \mathrm{MS}\left(\mathrm{CI}-\mathrm{NH}_{3}\right): 253\left(\mathrm{M}+\mathrm{H}^{+}\right.$, 9), 221 (8), 150 (7), 120 (100), 91 (17). Electrospray: 253.31. Anal. $\left(\mathrm{C}_{13} \mathrm{H}_{20} \mathrm{~N}_{2} \mathrm{O}_{3}\right) \mathrm{C} 61.76, \mathrm{H}$ 7.95, N 11.08.

tert-Butyl (3aR,4R,6aS)-4-(\{[(1S)-2-Hydroxy-1-phenylethyl]amino\}methyl)-2,2-dimethyl tetrahydro-5H-[1,3]dioxolo[4,5-c]pyrrole-5-carboxylate ((+)-6b). Procedure 1: 5 (97 $\mathrm{mg}, 0.36 \mathrm{mmol}), \mathrm{L}-(+)-\alpha$-phenylglycinol $(49 \mathrm{mg}, 0.36 \mathrm{mmol})$, $\mathrm{NaBH}(\mathrm{OAc})_{3}(106 \mathrm{mg}, 0.50 \mathrm{mmol}), \mathrm{ClCH}_{2} \mathrm{CH}_{2} \mathrm{Cl}(3 \mathrm{~mL}) . \mathrm{FC}$ (EtOAc): $84 \mathrm{mg}(60 \%), 1.7: 1$ mixture of rotamers. ${ }^{1} \mathrm{H}$ NMR $(400$ $\mathrm{MHz}, \mathrm{MeOD}) \delta$ : 7.37-7.26 (m, 5H), $4.76(\mathrm{~m}, 1 \mathrm{H}), 4.56\left(\mathrm{~d}, 1 \mathrm{H}_{\alpha}\right)$, $4.49\left(\mathrm{~d}, 1 \mathrm{H}_{\beta}\right), 4.14\left(\mathrm{dd}, 1 \mathrm{H}_{\beta}\right), 4.00(\mathrm{dd}, 1 \mathrm{H} \alpha), 3.76(\mathrm{~m}, 2 \mathrm{H}), 3.68-$ $3.52(\mathrm{~m}, 2 \mathrm{H}), 3.36(\mathrm{~m}, 1 \mathrm{H}), 2.66(\mathrm{~m}, 1 \mathrm{H}), 2.46(\mathrm{dd}, 1 \mathrm{H}), 1.50$ $(\mathrm{s}, 3 \mathrm{H}), 1.43,1.41(2 \mathrm{~s}, 9 \mathrm{H}), 1.30(\mathrm{~s}, 3 \mathrm{H}) .{ }^{13} \mathrm{C} \mathrm{NMR}(101 \mathrm{MHz}$, MeOD) $\delta$ : 157.2, 142.8, 130.4, 129.7, 129.5, 113.4, 85.7, 85.3, 82.2, 82.1, 81.7, 80.9, 68.8, 67.4, 66.3, 65.7, 54.4, 53.6, 50-49, 29.5, 28.1, 25.8. MS (CI- $\left.\mathrm{NH}_{3}\right): 394$ (100), $393\left(\mathrm{M}+\mathrm{H}^{+}, 49\right)$, 362 (55), 338 (16), 306 (35), 262 (13), 199 (16), 150 (72), 91 (48). Anal. $\left(\mathrm{C}_{21} \mathrm{H}_{32} \mathrm{~N}_{2} \mathrm{O}_{5}\right) \mathrm{C} 64.33, \mathrm{H}$ 8.33, N 7.01.

$(2 R, 3 R, 4 S)-2-(\{[(1 S)-2-H y d r o x y-1-p h e n y l e t h y l]$ amino $\}$ methyl)pyrrolidine-3,4-diol $((+)-7 \mathbf{b})$. Procedure 2 : $6 \mathbf{b}(30$ $\mathrm{mg}), 4 \mathrm{M} \mathrm{HCl}$. FC $\left(\mathrm{CH}_{3} \mathrm{CN} / \mathrm{NH}_{4} \mathrm{OH} 4: 1\right): 19 \mathrm{mg}(100 \%)$. $[\alpha]_{589}{ }^{25}$ $=+42,[\alpha]_{577}{ }^{25}=+46,[\alpha]_{546}{ }^{25}=+50,[\alpha]_{435}{ }^{25}=+85,[\alpha]_{405}{ }^{25}=$ $+99\left(c=0.55, \mathrm{H}_{2} \mathrm{O}\right) .{ }^{1} \mathrm{H}$ NMR $(400 \mathrm{MHz}, \mathrm{MeOD}) \delta: 7.42-$ 7.31 (m, 5H), 4.24 (ddd, 1H), 3.97 (dd, 1H), 3.83 (dd, $1 \mathrm{H}), 3.70$ (dd, $1 \mathrm{H}), 3.64(\mathrm{dd}, 1 \mathrm{H}), 3.57(\mathrm{ddd}, 1 \mathrm{H}), 3.43(\mathrm{dd}, 1 \mathrm{H}), 3.27(\mathrm{dd}$, $1 \mathrm{H}), 2.91$ (dd, 1H), 2.80 (dd, 1H). ${ }^{13} \mathrm{C} \mathrm{NMR}(101 \mathrm{MHz}, \mathrm{MeOD})$ $\delta: 142.5,130.6,129.6,129.5,75.4,72.0,68.5,66.9,62.9,51.8$, 47.7. $\mathrm{MS}\left(\mathrm{CI}-\mathrm{NH}_{3}\right): 253\left(\mathrm{M}+\mathrm{H}^{+}, 14\right), 221(8), 235(2), 195$ (4), 138 (36), 116 (48), 98 (100), 84 (47). Anal. $\left(\mathrm{C}_{13} \mathrm{H}_{20} \mathrm{~N}_{2} \mathrm{O}_{3}\right) \mathrm{C}$ 61.91, H 7.92, N 11.22.

tert-Butyl $\quad(3 \mathrm{a} R, 4 R, 6 \mathrm{a} S)-4-(\{[(1 R, 2 S)-2-H y d r o x y-1,2-$ diphenylethyl]amino\}methyl)-2,2-dimethyltetrahydro$5 H$-[1,3] dioxolo[4,5-c]pyrrole-5-carboxylate ((-)-6c). Procedure 1: 5 (114 mg, $0.42 \mathrm{mmol}),(1 S, 2 R)$-2-amino-1,2diphenylethanol (90 mg, $0.42 \mathrm{mmol}), \mathrm{NaBH}(\mathrm{OAc})_{3}$ (125 mg, $0.59 \mathrm{mmol}), \mathrm{ClCH}_{2} \mathrm{CH}_{2} \mathrm{Cl}(4 \mathrm{~mL}) . \mathrm{FC}$ (EtOAc/light petroleum 1:1): $120 \mathrm{mg}$ (61\%), 1.2:1 mixture of rotamers. ${ }^{1} \mathrm{H}$ NMR $(400$ $\left.\mathrm{MHz} \mathrm{CDCl}_{3}\right) \delta: 7.41-7.14(\mathrm{~m}, 10 \mathrm{H}), 4.77(\mathrm{~d}, 1 \mathrm{H}), 4.56(\mathrm{~m}$,
$1 \mathrm{H}), 4.47(\mathrm{~m}, 1 \mathrm{H}), 4.08\left(\mathrm{~m}, 1 \mathrm{H}_{\beta}\right), 3.94\left(\mathrm{~m}, 1 \mathrm{H}_{\alpha}\right), 3.88(\mathrm{~d}, 1 \mathrm{H})$ $3.82\left(\mathrm{~d}, 1 \mathrm{H}_{\alpha}\right), 3.73\left(\mathrm{~d}, 1 \mathrm{H}_{\beta}\right), 3.28(\mathrm{~m}, 1 \mathrm{H}), 2.51(\mathrm{~m}, 2 \mathrm{H}), 1.45$, 1.36, $1.32(3 \mathrm{~s}, 15 \mathrm{H}),{ }^{13} \mathrm{C}$ NMR $\left(101 \mathrm{MHz} \mathrm{CDCl}_{3}\right) \delta: 154.4$, 154.2, 140.4, 139.2, 128.0, 127.9, 127.7, 126.7, 111.5, 83.8, 83.0, $79.7,79.3,78.6,77.0,69.1,68.9,63.8,63.4,52.1,48.0,47.4$, 28.3, 26.9, 24.9. MS (CI- $\left.\mathrm{NH}_{3}\right): 469\left(\mathrm{M}+\mathrm{H}^{+}, 100\right), 413$ (21), 361 (14), 305 (22), 261 (7), 186 (5), 142 (12). Anal. $\left(\mathrm{C}_{27} \mathrm{H}_{36} \mathrm{~N}_{2} \mathrm{O}_{5}\right)$ C 69.29, H 7.83, N 5.95.

$(2 R, 3 R, 4 S)-2-(\{[(1 R, 2 S)-2-H y d r o x y-1,2-d i p h e n y l e t h y l]-$ amino\}methyl)pyrrolidine-3,4-diol $((+)-7 c)$. Procedure 2 : 6c $(50 \mathrm{mg}), 4: 1 \mathrm{CF}_{3} \mathrm{COOH} / \mathrm{H}_{2} \mathrm{O}$. $\mathrm{FC}\left(\mathrm{CH}_{3} \mathrm{CN} / \mathrm{NH}_{4} \mathrm{OH} 4: 1\right): 35$ $\mathrm{mg}(100 \%) .{ }^{1} \mathrm{H}$ NMR $(400 \mathrm{MHz}, \mathrm{MeOD}) \delta: 7.29-7.12(\mathrm{~m}, 10 \mathrm{H})$, $5.06(\mathrm{~d}, 1 \mathrm{H}), 4.17(\mathrm{~m}, 1 \mathrm{H}), 4.07(\mathrm{~d}, 1 \mathrm{H}), 3.88(\mathrm{dd}, 1 \mathrm{H}), 3.52(\mathrm{~m}$, $1 \mathrm{H}), 3.35(\mathrm{dd}, 1 \mathrm{H}), 3.23(\mathrm{dd}, 1 \mathrm{H}), 2.98(\mathrm{dd}, 1 \mathrm{H}), 2.67(\mathrm{~m}, 1 \mathrm{H})$.

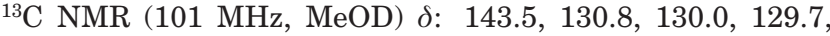
$129.3,128.8,77.8,75.8,71.8,71.2,62.5,51.7,48.0$. MS (CI$\left.\mathrm{NH}_{3}\right): 329\left(\mathrm{M}+\mathrm{H}^{+}, 57\right), 308$ (2), 275 (3), $244(3), 221$ (100), 197 (9), 152 (6), 118 (35), 106 (66), 91 (40), 77 (49).

tert-Butyl $\quad(3 \mathrm{a} R, 4 R, 6 \mathrm{aS})-4-(\{[(1 S, 2 R)-2-H y d r o x y-1,2-$ diphenylethyl]amino methyl)-2,2-dimethyltetrahydro$\mathbf{5 H}-[1,3]$ dioxolo $[4,5$-c] pyrrole-5-carboxylate $((-)-6 \mathrm{~d})$. Procedure 1: 5 (104 $\mathrm{mg}, 0.38 \mathrm{mmol}),(1 R, 2 S)$-2-amino-1,2diphenylethanol ( $82 \mathrm{mg}, 0.38 \mathrm{mmol}), \mathrm{NaBH}(\mathrm{OAc})_{3}(114 \mathrm{mg}$, $0.54 \mathrm{mmol}), \mathrm{ClCH}_{2} \mathrm{CH}_{2} \mathrm{Cl}(4 \mathrm{~mL})$. FC (EtOAc/light petroleum 1:1): $69 \mathrm{mg}$ (38\%), 1.2:1 mixture of rotamers. ${ }^{1} \mathrm{H}$ NMR $(400$ $\left.\mathrm{MHz}, \mathrm{CDCl}_{3}\right) \delta: 7.27-7.08(\mathrm{~m}, 10 \mathrm{H}), 4.79\left(\mathrm{~d}, 1 \mathrm{H}_{\alpha}\right), 4.75(\mathrm{~d}$, $\left.1 \mathrm{H}_{\beta}\right), 4.63(\mathrm{~m}, 1 \mathrm{H}), 4.39\left(\mathrm{~d}, 1 \mathrm{H}_{\beta}\right), 4.34\left(\mathrm{~d}, 1 \mathrm{H}_{\alpha}\right), 4.19\left(\mathrm{dd}, 1 \mathrm{H}_{\beta}\right)$, $4.02\left(\mathrm{~d}, 1 \mathrm{H}_{\alpha}\right), 3.97\left(\mathrm{dd}, 1 \mathrm{H}_{\beta}\right), 3.85-3.74(\mathrm{~m}, 2 \mathrm{H}), 3.15(\mathrm{~m}, 1 \mathrm{H})$, $2.60-2.38(\mathrm{~m}, 2 \mathrm{H}), 1.45,1.42(2 \mathrm{~s}, 9 \mathrm{H}), 1.39,1.28(2 \mathrm{~s}, 6 \mathrm{H}) .{ }^{13} \mathrm{C}$ NMR $\left(101 \mathrm{MHz}, \mathrm{CDCl}_{3}\right) \delta: 155.0,154.5,140.1,139.2,128.3$, $128.2,128.1,127.8,127.6,126.9,126.7,111.5,83.9,83.1,80.0$, $79.9,79.3,78.7,77.2,69.1,68.1,63.9,62.8,52.1,51.8,47.8$, 47.2, 28.3, 26.9, 25.0. MS (CI- $\left.\mathrm{NH}_{3}\right): 469\left(\mathrm{M}+\mathrm{H}^{+}, 100\right), 413$ (26), 361 (10), 305 (20), 261 (5), 186 (2), 142 (10), 84 (12). Anal. $\left(\mathrm{C}_{27} \mathrm{H}_{36} \mathrm{~N}_{2} \mathrm{O}_{5}\right) \mathrm{C} 69.30, \mathrm{H}$ 7.69, N 5.94.

$(2 R, 3 R, 4 S)-2-(\{[(1 S, 2 R)-2-H y d r o x y-1,2-d i p h e n y l e t h y l]-$ amino\}methyl)pyrrolidine-3,4-diol ((+)-7d). Procedure 2 : 6d $(52 \mathrm{mg}), 4: 1 \mathrm{CF}_{3} \mathrm{COOH} / \mathrm{H}_{2} \mathrm{O}$. FC $\left(\mathrm{CH}_{3} \mathrm{CN} / \mathrm{NH}_{4} \mathrm{OH} 4: 1\right): 36$ $\mathrm{mg}(100 \%) .{ }^{1} \mathrm{H}$ NMR (400 MHz, MeOD) $\delta: 7.30-7.14$ (m, 10H), $4.95(\mathrm{~d}, 1 \mathrm{H}), 4.20(\mathrm{ddd}, 1 \mathrm{H}), 3.96(\mathrm{~d}, 1 \mathrm{H}), 3.88(\mathrm{dd}, 1 \mathrm{H}), 3.49$ (ddd, $1 \mathrm{H}), 3.32(\mathrm{dd}, 1 \mathrm{H}), 3.22(\mathrm{dd}, 1 \mathrm{H}), 2.82(\mathrm{dd}, 1 \mathrm{H}), 2.76(\mathrm{dd}$, $1 \mathrm{H}) .{ }^{13} \mathrm{C}$ NMR (101 MHz, MeOD) $\delta: 143.8,141.2,130.6,129.9$, $129.7,129.3,129.0,78.9,75.4,72.0,70.5,62.9,51.7,47.7 . \mathrm{MS}$ $\left(\mathrm{CI}-\mathrm{NH}_{3}\right): 329\left(\mathrm{M}+\mathrm{H}^{+}, 23\right), 221(19), 197(44), 180(10), 133$ (33), 105 (100), 91 (61), 77 (52).

tert-Butyl (3aR,4R,6R,6aS $)-4-(\{[(1 R)-2-H y d r o x y-1-$ phenylethyl] amino\}methyl)-6-[(methoxymethoxy)methyl]-2,2-dimethyltetrahydro-5H-[1,3]dioxolo[4,5-c]pyrrole5-carboxylate ((-)-9). Dimethylsulfoxide (DMSO) $(35 \mu \mathrm{L}$, $0.50 \mathrm{mmol}, 2.4$ equiv) was added to a solution of oxalyl chloride ( $21 \mu \mathrm{L}, 0.24 \mathrm{mmol}, 1.15$ equiv) in anhydrous dichloromethane $(1.5 \mathrm{~mL})$ and cooled to $-78^{\circ} \mathrm{C}$. After $20 \mathrm{~min}$, alcohol 8 (72 $\mathrm{mg}$, $0.21 \mathrm{mmol}, 1$ equiv) in solution in anhydrous dichloromethane $(2.5 \mathrm{~mL})$ was added dropwise. After $20 \mathrm{~min}$, triethylamine (144 $\mu \mathrm{L}, 1.04 \mathrm{mmol}, 5$ equiv) was added, and the mixture was warmed to $-30{ }^{\circ} \mathrm{C}$ for $20 \mathrm{~min}$. The mixture was poured into water $(5 \mathrm{~mL})$ and extracted with dichloromethane $(5 \mathrm{~mL}, 3$ times). The combined organic phases were washed with brine (5 mL), dried over $\mathrm{MgSO}_{4}$, filtered, and concentrated in vacuo to afford a crude aldehyde. Sodium triacetoxyborohydride (62 $\mathrm{mg}, 0.29 \mathrm{mmol}, 1.4$ equiv) was added portionwise to a stirred solution of the crude aldehyde $(0.21 \mathrm{mmol}, 1$ equiv) and $\mathrm{d}-(-)$ $\alpha$-phenylglycinol (29 mg, $0.21 \mathrm{mmol}, 1$ equiv) in anhydrous dichloroethane $(2 \mathrm{~mL})$. After being stirred at room temperature overnight, the solution was poured into a saturated aqueous solution of $\mathrm{NaHCO}_{3}(5 \mathrm{~mL})$. The organic layer was collected, and the aqueous layer was extracted with $\mathrm{CH}_{2} \mathrm{Cl}_{2}(5 \mathrm{~mL}, 3$ times). The combined organic extracts were dried $\left(\mathrm{MgSO}_{4}\right)$. Solvent evaporation in vacuo and flash chromatography on silica gel (EtOAc) afforded (-)-9 (63 mg, 65\%, 2 steps). ${ }^{1} \mathrm{H}$ NMR $\left(400 \mathrm{MHz}, \mathrm{CDCl}_{3}\right) \delta: 7.38-7.26(\mathrm{~m}, 5 \mathrm{H}), 4.79$ (dd, $\left.1 \mathrm{H}\right), 4.67$ $(\mathrm{s}, 2 \mathrm{H}), 4.64(\mathrm{~m}, 1 \mathrm{H}), 4.39-3.99(\mathrm{~m}, 2 \mathrm{H}), 3.89(\mathrm{~m}, 1 \mathrm{H}), 3.81-$ $3.69(\mathrm{~m}, 4 \mathrm{H}), 3.55(\mathrm{dd}, 1 \mathrm{H}), 3.39(\mathrm{~s}, 3 \mathrm{H}), 2.66(\mathrm{~m}, 2 \mathrm{H}), 1.53$, $1.39(2 \mathrm{~s}, 15 \mathrm{H}) .{ }^{13} \mathrm{C} \mathrm{NMR}\left(101 \mathrm{MHz}, \mathrm{CDCl}_{3}\right) \delta: 154.2,140.2$, 
$128.7,127.8,127.0,111.6,96.8,82.0,80.3,79.5,66.8,64.9,64.1$, 61.0, 55.2, 47.8, 28.3, 26.2, 25.0. MS (CI- $\left.\mathrm{NH}_{3}\right): 467\left(\mathrm{M}+\mathrm{H}^{+}\right.$, 100), 437 (17), 379 (9), 335 (6), 150 (7). Anal. $\left(\mathrm{C}_{24} \mathrm{H}_{38} \mathrm{~N}_{2} \mathrm{O}_{7}\right) \mathrm{C}$ $61.88, \mathrm{H} 8.24, \mathrm{~N} 6.12$.

$(2 R, 3 S, 4 R, 5 R)-2-(H y d r o x y m e t h y l)-5-(\{[(1 R)-2-h y d r o x y-$ 1-phenylethyl]amino methyl)pyrrolidine-3,4-diol $((+)$ 10). Procedure 2: $9(26 \mathrm{mg}), 4 \mathrm{M} \mathrm{HCl}$. $\mathrm{FC}\left(\mathrm{CH}_{3} \mathrm{CN} / \mathrm{NH}_{4} \mathrm{OH}\right.$ 4:1): $16 \mathrm{mg}(100 \%) .{ }^{1} \mathrm{H}$ NMR $\left(400 \mathrm{MHz}, \mathrm{D}_{2} \mathrm{O}\right) \delta: 7.58-7.50$ $(\mathrm{m}, 5 \mathrm{H}), 4.35(\mathrm{dd}, 1 \mathrm{H}), 4.20(\mathrm{~m}, 1 \mathrm{H}), 4.16(\mathrm{dd}, 1 \mathrm{H}), 4.03(\mathrm{dd}$, $1 \mathrm{H}), 3.95(\mathrm{~m}, 3 \mathrm{H}), 3.79(\mathrm{~m}, 1 \mathrm{H}), 3.65(\mathrm{~m}, 1 \mathrm{H}), 3.14(\mathrm{bd}, 2 \mathrm{H})$ ${ }^{13} \mathrm{C}$ NMR $\left(101 \mathrm{MHz}, \mathrm{D}_{2} \mathrm{O}\right) \delta: 138.8,131.7,131.5,130.5,76.6$ $72.7,66.7,66.2,64.3,61.4,60.4,48 . \mathrm{MS}\left(\mathrm{CI}-\mathrm{NH}_{3}\right): 283(\mathrm{M}+$ $\left.\mathrm{H}^{+}, 12\right), 247$ (2), 189 (3), 163 (15), 138 (100), 106 (54), 80 (9).

(2R)-2-(Diallylamino)-2-phenylethanol ((-)-11). NaH$\mathrm{CO}_{3}$ (2.45 g, $29.2 \mathrm{mmol}, 2$ equiv) and allyl bromide $(5.05 \mathrm{~mL}$, $58.3 \mathrm{mmol}, 4$ equiv) were added to a solution of $\mathrm{D}-(-)-\alpha-$ phenylglycinol ( $2 \mathrm{~g}, 14.6 \mathrm{mmol}, 1$ equiv) in THF/DMSO (40 $\mathrm{mL} / 10 \mathrm{~mL}$ ). A catalytic amount of tetrabutylammonium iodide (1.62 g, $4.38 \mathrm{mmol}, 0.3$ equiv) was added, and the reaction mixture was stirred at $60{ }^{\circ} \mathrm{C}$ for $3 \mathrm{~h}$. Water $(30 \mathrm{~mL})$ was added after the reaction warmed to room temperature. The reaction mixture was extracted with $\mathrm{CH}_{2} \mathrm{Cl}_{2}(75 \mathrm{~mL}, 3$ times), dried $\left(\mathrm{MgSO}_{4}\right)$, filtered, and concentrated in vacuo. Purification by flash chromatography (EtOAc/light petroleum 1:1) afforded $(-)-11$ as a pale yellow oil $(2.70 \mathrm{~g}, 85 \%)$. ${ }^{1} \mathrm{H}$ NMR $(400 \mathrm{MHz}$, MeOD) $\delta: 7.39-7.30$ (m, 3H, 7.22-7.20 (m, 2H), 5.82 (dddd, $2 \mathrm{H}), 5.19(\mathrm{~m}, 4 \mathrm{H}), 4.01(\mathrm{~m}, 2 \mathrm{H}), 3.63(\mathrm{dd}, 1 \mathrm{H}), 3.40(\mathrm{~m}, 2 \mathrm{H})$, $2.73(\mathrm{dd}, 2 \mathrm{H}) .{ }^{13} \mathrm{C}$ NMR (101 MHz, MeOD) $\delta: 136.4,135.7$, 129.0, 128.3, 127.8, 117.7, 63.4, 60.4, 52.4. $\mathrm{MS}\left(\mathrm{CI}-\mathrm{NH}_{3}\right): 218$ $\left(\mathrm{M}+\mathrm{H}^{+}, 100\right), 186$ (32), 98 (4). Anal. $\left(\mathrm{C}_{14} \mathrm{H}_{19} \mathrm{NO}\right) \mathrm{C} 77.51, \mathrm{H}$ 8.93 .

$\boldsymbol{N}, \boldsymbol{N}$-Diallyl- $\boldsymbol{N}$-[(1R)-2-methoxy-1-phenylethyl]amine ((-)-12). Diallylamine 11 (169 $\mathrm{mg}, 0.78 \mathrm{mmol}, 1$ equiv) was dissolved in anhydrous THF ( $3 \mathrm{~mL})$, under argon atmosphere, and the temperature was cooled to $0{ }^{\circ} \mathrm{C}$. Sodium hydride $(41$ $\mathrm{mg}, 0.93 \mathrm{mmol}, 1.2$ equiv, $55 \%$ in oil) was added and the reaction mixture was stirred at $0{ }^{\circ} \mathrm{C}$ for $10 \mathrm{~min}$. Methyl iodide ( $86 \mu \mathrm{L}, 0.93 \mathrm{mmol}, 1.2$ equiv) was added, and the mixture was allowed to warm to room temperature. After $2 \mathrm{~h}$, the resulting mixture was poured into a saturated aqueous solution of $\mathrm{NaHCO}_{3}(5 \mathrm{~mL})$ and the aqueous layer was extracted with EtOAc ( $5 \mathrm{~mL}, 3$ times). The combined organic extracts were dried $\left(\mathrm{MgSO}_{4}\right)$, filtered, and concentrated in vacuo. Flash chromatography on silica gel (EtOAc/light petroleum 1:9)

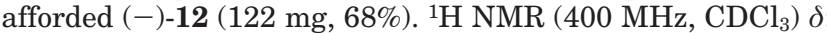
$7.37-7.26(\mathrm{~m}, 5 \mathrm{H}), 5.91-5.82(\mathrm{~m}, 2 \mathrm{H}), 5.16(\mathrm{~m}, 4 \mathrm{H}), 4.04(\mathrm{t}$, $1 \mathrm{H}), 3.81(\mathrm{dd}, 1 \mathrm{H}), 3.71(\mathrm{dd}, 1 \mathrm{H}), 3.35(\mathrm{~s}, 3 \mathrm{H}, \mathrm{Me}), 3.28(\mathrm{dd}$, $2 \mathrm{H}), 2.99(\mathrm{dd}, 2 \mathrm{H}) .{ }^{13} \mathrm{C} \mathrm{NMR}\left(101 \mathrm{MHz}, \mathrm{CDCl}_{3}\right) \delta: 139.3,136.6$, $128.5,128.1,127.1,117.0,73.8,62.7,58.9,53.2 . \mathrm{MS}\left(\mathrm{CI}-\mathrm{NH}_{3}\right)$ : $232\left(\mathrm{M}+\mathrm{H}^{+}, 100\right), 186$ (97), 135 (12), 117 (2), 91 (11). Anal. $\left(\mathrm{C}_{15} \mathrm{H}_{21} \mathrm{NO}\right) \mathrm{C} 72.71, \mathrm{H} 9.12, \mathrm{~N} 6.11$.

$\boldsymbol{N}, \boldsymbol{N}$-Diallyl- $\boldsymbol{N}$-[(1R)-2-(benzyloxy)-1-phenylethyl]amine ((-)-13). Diallylamine 11 (307 mg, $1.41 \mathrm{mmol}, 1$ equiv) was dissolved in anhydrous THF $(5 \mathrm{~mL})$, under argon atmosphere, and the temperature was cooled to $0{ }^{\circ} \mathrm{C}$. Sodium hydride (74 mg, $1.70 \mathrm{mmol}, 1.2$ equiv, $55 \%$ in oil) was added, and the mixture was stirred at $0{ }^{\circ} \mathrm{C}$ for $10 \mathrm{~min}$. Benzyl bromide (201 $\mu \mathrm{L}, 1.70 \mathrm{mmol}, 1.2$ equiv) was added, and the mixture was allowed to warm to room temperature for $12 \mathrm{~h}$. The resulting mixture was poured into a saturated aqueous solution of $\mathrm{NaHCO}_{3}(10 \mathrm{~mL})$, and the aqueous layer was extracted with EtOAc (15 mL, 3 times). The combined organic extracts were dried $\left(\mathrm{MgSO}_{4}\right)$, filtered, and concentrated in vacuo. Flash chromatography on silica gel (EtOAc/light petroleum 1:9) afforded (-)-13 (430 mg, 100\%). ${ }^{1} \mathrm{H}$ NMR (400 $\mathrm{MHz}^{\left.-\mathrm{CDCl}_{3}\right)}$ $\delta: 7.44-7.25(\mathrm{~m}, 10 \mathrm{H}), 5.95-5.85(\mathrm{~m}, 2 \mathrm{H}), 5.24-5.15(\mathrm{~m}, 4 \mathrm{H})$, $4.55(\mathrm{~s}, 2 \mathrm{H}), 4.13(\mathrm{t}, 1 \mathrm{H}), 3.92(\mathrm{dd}, 1 \mathrm{H}), 3.82(\mathrm{dd}, 1 \mathrm{H}), 3.31$ $(\mathrm{dd}, 2 \mathrm{H}), 3.07$ (dd, $2 \mathrm{H}) .{ }^{13} \mathrm{C} \mathrm{NMR}\left(101 \mathrm{MHz}, \mathrm{CDCl}_{3}\right) \delta: 138.3$, $136.4,128.5,128.2,128.0,127.5,127.4,127.0,117.0,73.0,71.2$, 63.0, 53.2. MS $\left(\mathrm{CI}-\mathrm{NH}_{3}\right): 308\left(\mathrm{M}+\mathrm{H}^{+}, 71\right), 186(100), 144$ (6), $91(60)$.

$(2 R, 3 R, 4 S)-2-(\{[(1 R)-2-M e t h o x y-1-p h e n y l e t h y l]$ amino $\}-$ methyl)pyrrolidine-3,4-diol ((+)-18). A mixture of $\mathrm{Pd}(\mathrm{dba})_{2}$ $\left(4.11 \times 10^{-5} \mathrm{~mol}\right)$ and DPPB $\left(8.22 \times 10^{-5} \mathrm{~mol}\right)$ in THF $(0.5$
$\mathrm{mL}$ ) was stirred at room temperature, under argon atmosphere for $15 \mathrm{~min}$. The so-formed catalyst and 2-mercaptobenzoid acid ( 2.2 equiv, $0.904 \mathrm{mmol})$ were added to the solution of $\mathbf{1 2}(95$ $\mathrm{mg}, 0.411 \mathrm{mmol})$ in anhydrous THF $(3 \mathrm{~mL})$, and the reaction was stirred at $60{ }^{\circ} \mathrm{C}$ for $12 \mathrm{~h}$. The mixture was poured into a $1 \mathrm{M} \mathrm{HCl}$ solution $(10 \mathrm{~mL})$ and extracted with EtOAc $(10 \mathrm{~mL}$, 2 times). The aqueous layer was treated with $1 \mathrm{M} \mathrm{NaOH}$ and extracted with EtOAc (10 mL, 3 times). The combined organic extracts were dried $\left(\mathrm{MgSO}_{4}\right)$ and concentrated in vacuo to afford 15 (62 mg, 100\% crude). Procedure 1 was applied on 5 (111 $\mathrm{mg}, 0.41 \mathrm{mmol})$ and $15(62 \mathrm{mg}, 0.41 \mathrm{mmol})$ in the presence of $\mathrm{NaBH}(\mathrm{OAc})_{3}(122 \mathrm{mg}, 1.34 \mathrm{mmol})$ in $\mathrm{ClCH}_{2} \mathrm{CH}_{2} \mathrm{Cl}(3 \mathrm{~mL})$. FC (EtOAc/light petroleum 1:1): $123 \mathrm{mg}$ (74\%), 1.4:1 mixture of rotamers. This intermediate was treated according to procedure 2 in $4: 1 \mathrm{CF}_{3} \mathrm{COOH} / \mathrm{H}_{2} \mathrm{O}$. $\mathrm{FC}\left(\mathrm{CH}_{3} \mathrm{CN} / \mathrm{NH}_{4} \mathrm{OH} 4: 1\right)$ : (+)-18, $81 \mathrm{mg}(100 \%)$.

Data for Intermediate tert-Butyl $(3 a R, 4 R, 6 a S)-4$ (\{[(1R)-2-Methoxy-1-phenylethyl]amino $\}$ methyl)-2,2dimethyltetrahydro-5H-[1,3]dioxolo[4,5-c]pyrrole-5-carboxylate. ${ }^{1} \mathrm{H}$ NMR $(400 \mathrm{MHz}, \mathrm{MeOD}) \delta: 7.39-7.26(\mathrm{~m}, 5 \mathrm{H})$, $4.69(\mathrm{~m}, 1 \mathrm{H}), 4.60\left(\mathrm{~d}, 1 \mathrm{H}_{\alpha}\right), 4.55\left(\mathrm{~d}, 1 \mathrm{H}_{\beta}\right), 4.09\left(\mathrm{dd}, 1 \mathrm{H}_{\beta}\right), 4.04$ $\left(\mathrm{dd}, 1 \mathrm{H}_{\alpha}\right), 3.88(\mathrm{~m}, 1 \mathrm{H}), 3.76(\mathrm{~m}, 1 \mathrm{H}), 3.50(\mathrm{~m}, 2 \mathrm{H}), 3.38(\mathrm{~s}$, $3 \mathrm{H}), 3.33(\mathrm{~m}, 1 \mathrm{H}), 2.60-2.40(\mathrm{~m}, 2 \mathrm{H}), 1.48(\mathrm{~s}, 3 \mathrm{H}), 1.41(\mathrm{~s}, 9$ $\mathrm{H}), 1.31(\mathrm{~s}, 3 \mathrm{H}) .{ }^{13} \mathrm{C}$ NMR $(101 \mathrm{MHz}, \mathrm{MeOD}) \delta: 157.4,157.1$, $142.5,130.4,129.6,129.5,113.4,85.4,84.9,82.3,82.1,81.6$, $80.9,79.4,79.2,66.2,65.7,64.9,64.5,59.953 .8,53.3,50-49$, 29.5, 28.1, 25.9. MS (CI- $\left.\mathrm{NH}_{3}\right): 407\left(\mathrm{M}+\mathrm{H}^{+}, 100\right), 361(10)$, 305 (5), 164 (9), 106 (3). Anal. $\left(\mathrm{C}_{22} \mathrm{H}_{34} \mathrm{~N}_{2} \mathrm{O}_{5}\right) \mathrm{C} 64.95, \mathrm{H} 8.50$.

Data for $(+)-18 .{ }^{1} \mathrm{H}$ NMR $(400 \mathrm{MHz}, \mathrm{MeOD}) \delta: 7.50-7.37$ $(\mathrm{m}, 5 \mathrm{H}), 4.26(\mathrm{~m}, 1 \mathrm{H}), 4.23(\mathrm{ddd}, 1 \mathrm{H}), 3.98(\mathrm{dd}, 1 \mathrm{H}), 3.68(\mathrm{~m}$, $2 \mathrm{H}), 3.63(\mathrm{~m}, 1 \mathrm{H}), 3.50(\mathrm{dd}, 1 \mathrm{H}), 3.42(\mathrm{~s}, 3 \mathrm{H}), 3.29(\mathrm{dd}, 1 \mathrm{H})$, $3.20(\mathrm{~m}, 1 \mathrm{H}), 3.08(\mathrm{dd}, 1 \mathrm{H}) .{ }^{13} \mathrm{C}$ NMR $(101 \mathrm{MHz}, \mathrm{MeOD}) \delta$ : 138.4, 131.0, 130.8, 130.0, 76.7, 75.9, 71.4, 65.0, 61.3, 60.2, 52.0, 47.9. CI-MS (CI- $\left.\mathrm{NH}_{3}\right): 267\left(\mathrm{M}+\mathrm{H}^{+}, 100\right), 221(34), 164(22)$, 152 (9), 135 (35), 120 (39), 106 (19), 95 (10).

$(2 R, 3 R, 4 S)-2-(\{[(1 R)-2-(B e n z y l o x y)-1-p h e n y l e t h y l]-$ amino methyl)pyrrolidine-3,4-diol ((-)-19). A mixture of $\mathrm{Pd}(\mathrm{dba})_{2}\left(3.5 \times 10^{-5} \mathrm{~mol}\right)$ and DPPB $\left(7.0 \times 10^{-5} \mathrm{~mol}\right)$ in THF $(0.5 \mathrm{~mL})$ was stirred at room temperature, under argon atmosphere for $15 \mathrm{~min}$. The so-formed catalyst and 2-mercaptobenzoid acid ( 2.2 equiv, $0.7 \mathrm{mmol}$ ) were added to the solution of $13(108 \mathrm{mg}, 0.35 \mathrm{mmol})$ in anhydrous THF ( $3 \mathrm{~mL})$, and the reaction was stirred at $60{ }^{\circ} \mathrm{C}$ for $12 \mathrm{~h}$. The mixture was poured into a $1 \mathrm{M} \mathrm{HCl}$ solution $(10 \mathrm{~mL})$ and extracted with EtOAc (10 mL, 2 times). The aqueous layer was treated with $1 \mathrm{M}$ $\mathrm{NaOH}$ and extracted with EtOAc (10 mL, 3 times). The combined organic extracts were dried $\left(\mathrm{MgSO}_{4}\right)$ and concentrated in vacuo to afford 16 (79 mg, 100\% crude). Procedure 1 was applied on 5 (94 mg, $0.35 \mathrm{mmol})$ and 16 (79 $\mathrm{mg}, 0.35$ $\mathrm{mmol}$ ) in the presence of $\mathrm{NaBH}(\mathrm{OAc})_{3}(103 \mathrm{mg}, 0.49 \mathrm{mmol})$ in $\mathrm{ClCH}_{2} \mathrm{CH}_{2} \mathrm{Cl}(2.5 \mathrm{~mL}) . \mathrm{FC}$ (EtOAc/light petroleum 1:1): 101 $\mathrm{mg}(60 \%), 1.1: 1$ mixture of rotamers. This intermediate was treated according to procedure 2 in $4: 1 \mathrm{CF}_{3} \mathrm{COOH} / \mathrm{H}_{2} \mathrm{O}$. FC $\left(\mathrm{CH}_{3} \mathrm{CN} / \mathrm{NH}_{4} \mathrm{OH} 4: 1\right)$ : (-)-19, $72 \mathrm{mg}(100 \%)$.

Data for Intermediate tert-Butyl (3aR,4R,6aS)-4(\{[(1R)-2-(Benzyloxy)-1-phenylethyl] amino $\}$ methyl)-2,2 dimethyltetrahydro-5H-[1,3]dioxolo[4,5-c]pyrrole-5-carboxylate. ${ }^{1} \mathrm{H}$ NMR $(400 \mathrm{MHz}, \mathrm{MeOD}) \delta: 7.39-7.26(\mathrm{~m}, 10 \mathrm{H})$, $4.77-4.60(\mathrm{~m}, 2 \mathrm{H}), 4.56(\mathrm{~s}, 2 \mathrm{H}), 4.14-4.02(\mathrm{~m}, 1 \mathrm{H}), 3.92(\mathrm{~m}$, $1 \mathrm{H}), 3.76\left(\mathrm{~d}, 1 \mathrm{H}_{\alpha}\right), 3.74\left(\mathrm{~d}, 1 \mathrm{H}_{\beta}\right), 3.55(\mathrm{~m}, 2 \mathrm{H}), 3.36(\mathrm{~m}, 1 \mathrm{H})$, $2.61-2.42(\mathrm{~m}, 2 \mathrm{H}), 1.47,1.38(2 \mathrm{~s}, 9 \mathrm{H}), 1.42(\mathrm{~s}, 3 \mathrm{H}), 1.31(\mathrm{~s}$, $3 \mathrm{H}) .{ }^{13} \mathrm{C}$ NMR (101 MHz, MeOD): 157.3, 157.1, 142.6, 130.4, $130.3,129.8,129.6,129.5,113.4,85.4,85.0,82.3,82.1,81.6$, $80.9,77.0,76.9,75.0,66.2,65.8,65.1,64.6,53.9,53.4,50-49$, 29.5, 28.1, 25.9. MS $\left(\mathrm{CI}-\mathrm{NH}_{3}\right): 484\left(\mathrm{M}+\mathrm{H}^{+}, 100\right), 428(3)$, 362 (62), 305 (18), 241 (6), 142 (14), 91 (30). Anal. $\left(\mathrm{C}_{28} \mathrm{H}_{38} \mathrm{~N}_{2} \mathrm{O}_{5}\right)$ C 67.55, H 7.66.

Data for (-)-19. ${ }^{1} \mathrm{H}$ NMR $(400 \mathrm{MHz}, \mathrm{MeOD}) \delta: 7.42-7.29$ $(\mathrm{m}, 10 \mathrm{H}), 4.56(\mathrm{~s}, 2 \mathrm{H}), 4.21(\mathrm{dd}, 1 \mathrm{H}), 3.96(\mathrm{dd}, 1 \mathrm{H}), 3.91(\mathrm{dd}$, $1 \mathrm{H}), 3.63(\mathrm{~m}, 2 \mathrm{H}), 3.40(\mathrm{~m}, 2 \mathrm{H}), 3.19(\mathrm{dd}, 1 \mathrm{H}), 2.88(\mathrm{dd}, 1 \mathrm{H})$, 2.73 (dd, $1 \mathrm{H}),{ }^{13} \mathrm{C}$ NMR (101 MHz, MeOD) $\delta: 142.6,140.2$, $130.6,130.3,129.9,129.7,129.5,76.7,75.6,75.2,72.0,65.3$, 63.7, 51.5, 48.4. MS (CI- $\left.\mathrm{NH}_{3}\right): 343\left(\mathrm{M}+\mathrm{H}^{+}, 32\right), 306(3), 229$ (11), 195 (7), 159 (6), 120 (38), 106 (67), 91 (100). 
Data for (2S)-2-(\{[(2R, 3S, 4S)-3,4-Dihydroxypyrrolidin-2-yl]methyl \}amino)-2-phenylethyl 2-Fluorobenzoate ((-)-23). ${ }^{1} \mathrm{H}$ NMR (400 MHz, MeOD) $\delta: 7.88(\mathrm{~m}, 1 \mathrm{H}), 7.66-$ $7.62(\mathrm{~m}, 1 \mathrm{H}), 7.48-7.22(\mathrm{~m}, 7 \mathrm{H}), 4.50(\mathrm{~m}, 2 \mathrm{H}), 4.22$ (ddd, $1 \mathrm{H})$, $4.14\left(\mathrm{t}, 1 \mathrm{H},{ }^{3} J=6.1 \mathrm{~Hz}, \mathrm{H}-\mathrm{C}\left(1^{\prime \prime}\right)\right), 3.96(\mathrm{dd}, 1 \mathrm{H}), 3.48-3.38$ (m, 2H), $3.23(\mathrm{dd}, 1 \mathrm{H}), 2.98(\mathrm{dd}, 1 \mathrm{H}), 2.75(\mathrm{dd}, 1 \mathrm{H}) .{ }^{13} \mathrm{C} \mathrm{NMR}$

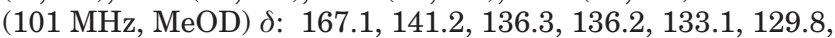
$129.1,128.6,125.4,118.1,117.9,74.8,71.2,69.7,63.3,62.7$, 50.8, 47.5. MALDI-TOF: $375(\mathrm{M}+\mathrm{H})^{+}$.

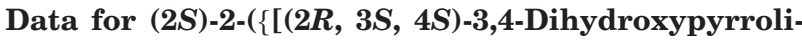
din-2-yl]methyl \}amino)-2-phenylethyl 4-Fluorobenzoate ((+)-24). ${ }^{1} \mathrm{H}$ NMR (400 MHz, MeOD) $\delta: 8.05$ (m, 2H), 7.48$7.33(\mathrm{~m}, 5 \mathrm{H}), 7.22(\mathrm{~m}, 1 \mathrm{H}), 4.53(\mathrm{dd}, 1 \mathrm{H}), 4.45(\mathrm{dd}, 1 \mathrm{H}), 4.22$ $(\mathrm{m}, 1 \mathrm{H}), 4.15(\mathrm{~m}, 1 \mathrm{H}), 3.95(\mathrm{dd}, 1 \mathrm{H}), 3.48(\mathrm{ddd}, 1 \mathrm{H}), 3.41$ (dd, $1 \mathrm{H}), 3.24(\mathrm{dd}, 1 \mathrm{H}), 2.99(\mathrm{dd}, 1 \mathrm{H}), 2.74(\mathrm{dd}, 1 \mathrm{H}) .{ }^{13} \mathrm{C} \mathrm{NMR}(101$ $\mathrm{MHz}, \mathrm{MeOD}) \delta$ : 173.0, 141.3, 133.4, 130.0, 129.8, 129.4, 129.0, 128.6, 116.7, 74.8, 71.1, 69.5, 63.4, 62.7, 50.7, 47.6. MALDITOF: $375(\mathrm{M}+\mathrm{H})^{+}$.

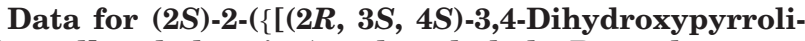
din-2-yl]methyl \}amino)-2-phenylethyl 3-Bromobenzoate ((-)-25). ${ }^{1} \mathrm{H}$ NMR $(400 \mathrm{MHz}, \mathrm{MeOD}) \delta: 8.11(\mathrm{~s}, 1 \mathrm{H}), 7.97(\mathrm{~d}$, $1 \mathrm{H}), 7.80(\mathrm{dd}, 1 \mathrm{H}), 7.49-7.41(\mathrm{~m}, 5 \mathrm{H}), 7.35(\mathrm{~d}, 1 \mathrm{H}), 4.55(\mathrm{dd}$, $1 \mathrm{H}), 4.46(\mathrm{dd}, 1 \mathrm{H}), 4.21$ (ddd, $1 \mathrm{H}), 4.14(\mathrm{dd}, 1 \mathrm{H}), 3.95(\mathrm{dd}, 1 \mathrm{H})$, $3.48-3.42$ (dd, $1 \mathrm{H}), 3.41-3.34(\mathrm{~m}, 1 \mathrm{H}), 3.22(\mathrm{dd}, 1 \mathrm{H}), 2.98(\mathrm{dd}$, $1 \mathrm{H}), 2.72(\mathrm{dd}, 1 \mathrm{H}),{ }^{13} \mathrm{C}$ NMR $(101 \mathrm{MHz}, \mathrm{MeOD}) \delta$ : 163.3 , 144.4 , 141.3, 138.8, 137.2, 133.4, 131.5,129.9, 129.3, 129.1, 128.6, 74.9, 71.2, 69.7, 63.4, 62.7, 50.8, 47.7. MALDI-TOF: 437 $(\mathrm{M}+2)^{+}, 435 \mathrm{M}^{+}$.

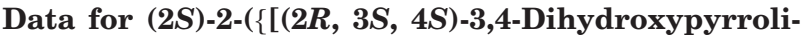
din-2-yl]methyl \}amino)-2-phenylethyl 4-Bromobenzoate ((-)-26). ${ }^{1} \mathrm{H}$ NMR $(400 \mathrm{MHz}, \mathrm{MeOD}) \delta: 7.90(\mathrm{~d}, 2 \mathrm{H}), 7.68(\mathrm{~d}$, $2 \mathrm{H}), 7.48-7.40(\mathrm{~m}, 4 \mathrm{H}), 7.28(\mathrm{~m}, 1 \mathrm{H}), 4.54(\mathrm{dd}, 1 \mathrm{H}), 4.46(\mathrm{dd}$, $1 \mathrm{H}), 4.22(\mathrm{~m}, 1 \mathrm{H}), 4.14(\mathrm{dd}, 1 \mathrm{H}), 3.95(\mathrm{dd}, 1 \mathrm{H}), 3.46(\mathrm{ddd}, 1 \mathrm{H})$, $3.41(\mathrm{~m}, 1 \mathrm{H}, \mathrm{H}-\mathrm{C}(5)), 3.23(\mathrm{dd}, 1 \mathrm{H}), 2.99(\mathrm{dd}, 1 \mathrm{H}), 2.73(\mathrm{dd}$, $1 \mathrm{H}) .{ }^{13} \mathrm{C}$ NMR $(101 \mathrm{MHz}, \mathrm{MeOD}) \delta: 170.0,141.3,133.0,132.3$, $130.3,129.9,129.2,129.1,128.6,74.8,71.1,69.6,63.4,62.7$, 50.7, 47.7. MALDI-TOF: $437(\mathrm{M}+2)^{+}, 435 \mathrm{M}^{+\bullet}$.

Data for 3-Bromo- $N-[(2 S)-2-(\{[(2 R, 3 S, 4 R)-3,4-d i h y d r o x y-$ pyrrolidin-2-yl]methyl \}amino)-2-phenylethyl]benzamide ((+)-29). ${ }^{1} \mathrm{H}$ NMR (400 MHz, MeOD): 7.93 (s, 1H), 7.72 (dd, $2 \mathrm{H}), 7.41-7.31(\mathrm{~m}, 6 \mathrm{H}), 4.25(\mathrm{~m}, 1 \mathrm{H}), 3.99(\mathrm{~m}, 2 \mathrm{H}), 3.67(\mathrm{dd}$ $1 \mathrm{H}), 3.59(\mathrm{dd}, 1 \mathrm{H}), 3.51-3.43(\mathrm{~m}, 2 \mathrm{H}, 3.28(\mathrm{dd}, 1 \mathrm{H}), 2.96(\mathrm{dd}$, $1 \mathrm{H}), 2.73$ (dd, 1H). ${ }^{13} \mathrm{C}$ NMR (101 MHz, MeOD): 169.0, 142.4, 137.7, 135.6, 131.4, 129.8, 128.9, 128.4, 127.1, 123.5, 74.7, 71.1, 64.1, 62.7, 50.6, 47.4, 46.8. MALDI-TOF: $436\left[(\mathrm{M}+2)^{+}\right], 434$ $\left(\mathrm{M}^{+\bullet}\right)$.

Biology. (A) Inhibition of Commercially Purified Plant Glycosidases. The experiments were performed essentially as previously described..$^{18}$ Briefly, $0.01-0.5$ units $/ \mathrm{mL}$ of enzyme ( 1 unit $=1 \mu \mathrm{mol}$ of glycoside hydrolyzed $/ \mathrm{min}$ ), preincubated for $5 \mathrm{~min}$ at $20^{\circ} \mathrm{C}$ with the inhibitor, and increasing concentration of aqueous solution of the appropriate $p$-nitrophenyl glycoside substrates buffered to the optimum $\mathrm{pH}$ of the enzyme were incubated for $20 \mathrm{~min}$ at $37^{\circ} \mathrm{C}\left(45^{\circ} \mathrm{C}\right.$ for the amyloglucosidases). The reaction was stopped by the addition of a 2.5 volume of $0.2 \mathrm{M}$ sodium borate buffer $\mathrm{pH} 9.8$. The $p$-nitrophenolate formed was quantified at $410 \mathrm{~nm}$, and $\mathrm{IC}_{50}$ values were calculated or double-reciprocal (Lineweaver-Burk) plots were used to determine the inhibition characteristics.

(B) Cell Cultures and Treatments. Human LN18 and LNZ308 glioblastoma cell lines ${ }^{25}$ were routinely maintained in Dulbecco's Modified Eagle Medium (DMEM) (Gibco, Basel, Switzerland) containing $4.5 \mathrm{~g} /$ glucoses, $5 \%$ fetal calf serum (FCS, Gibco), and antibiotics. Human Me237 and Me275 cell lines $^{26}$ were grown in RPMI medium (Gibco) containing $10 \%$ FCS and antibiotics. Human primary fibroblasts were prepared from surgical skin (PG 98/5) or lung (PO 08) biopsies using the explant technique and grown in DMEM medium containing $4.5 \mathrm{~g} / \mathrm{L}$ glucose, $10 \%$ FCS, and antibiotics. For the experiments, cells were grown in 48 well plates (Costar, Corning, NY) for $24-72 \mathrm{~h}$ in the presence of FCS, and then exposed for the indicated time to increasing concentrations of pyrrolidine derivatives (from 0 to $300 \mu \mathrm{M}$, stock solutions in methanol/phosphate buffered saline (1:20)) in fresh complete medium. Then either metabolically active cells were quantified using the MTT assay (cf. below) or DNA synthesis and protein synthesis were evaluated using $\left[{ }^{3} \mathrm{H}\right]$-thymidine or $\left[{ }^{3} \mathrm{H}\right]$-leucine incorporation (cf. below). Experiments were performed in triplicate wells and were repeated at least three times. Means \pm SD have been calculated.

(C) Evaluation of Cell Proliferation by the MTT Assay. MTT (Sigma, Buchs, Switzerland) was used to quantify the number of metabolically active cells. The cells were exposed to $0.2 \mathrm{mg} / \mathrm{mL}$ MTT in DMEM medium for $2 \mathrm{~h}$ following treatment with pyrrolidine, the supernatant was aspirated, and the precipitated formazan was dissolved in $0.1 \mathrm{~N} \mathrm{HCl}$ in 2-propanol and quantified at $540 \mathrm{~nm}$ in a multiwell plate reader (iEMS Reader MF, Labsystems, Bioconcepts, Switzerland).

(D) Evaluation of DNA and Protein Synthesis. Thymidine and leucine incorporation were used to assess DNA and protein synthesis, respectively. $\left[{ }^{3} \mathrm{H}\right]$-Thymidine (AmershamPharmacia, Dübendorf, Switzerland, $400 \mathrm{nCi} /$ well) or $\left[{ }^{3} \mathrm{H}\right]-\mathrm{Leu}$ (American Radiolabeled Chemicals, St. Louis MO, $400 \mathrm{nCi} /$ puit) were added to treated or control cells for the last $2 \mathrm{~h}$ of incubation with the pyrrolidine derivatives. The cell layer was washed and precipitated with $10 \%$ trichloracetic acid, the precipitate was dissolved in $1 \%$ sodium dodecyl sulfate in 0.1 $\mathrm{N} \mathrm{NaOH}$; then $5 \mathrm{~mL}$ of scintillation cocktail (Optiphase, Wallac, Regensdorf, Switzerland) was added, and the radioactivity was counted in a $\beta$-counter (WinSpectral, Wallac).

Acknowledgment. We thank Mrs. A.C. Diserens, Neurosurgery Division, CHUV, Lausanne, for providing the glioblastoma cell lines Dr. D. Rimoldi, from the Ludwig Institute, Lausanne, for the gift of the human melanoma cells, and Mr. Martial Rey, Mr. Francisco Sepùlveda, and Dr. Alain Razaname for the technical help. This work was supported by grants from the Swiss League and Research against Cancer (Grant KFS 107009-2000 and Grant KLS-01308-02-2003), the Swiss National Foundation for Scientific Research (Grants 3152-059219.99, 3152A0-105705, 2100-063567.00/1, and 200020-100028/1), the Swiss Society for Multiple Sclerosis, and the Novartis Foundation for Scientific Research.

Supporting Information Available: Analytical and spectroscopic data for compounds (-)-6a, $(+)-\mathbf{7 a},(+)-\mathbf{6 b},(+)-\mathbf{7 b}$, $(-)-\mathbf{6 c},(+)-\mathbf{7 c},(-)-\mathbf{6 d},(+)-\mathbf{7 d},(-)-\mathbf{9},(+)-\mathbf{1 0},(-)-\mathbf{1 1},(-)-\mathbf{1 2},(-)$ 13, (+)-18, (-)-19, (-)-23, (+)-24, (-)-25, (-)-26, and (+)-29. Elemental analyses or HPLC data for target compounds is also present. This material is available free of charge via the Internet at http://pubs.acs.org.

\section{References}

(1) Donnelly, J. G. Pharmacogenetics in cancer chemotherapy: balancing toxicity and response. Ther. Drug Monit. 2004, 26, 231-235.

(2) Hakomori, S. Aberrant glycosylation in cancer cell membranes as focused on glycolipids: overview and perspectives. Cancer Res. 1985, 45, 2405-2414.

(3) Dennis, J. W.; Granovsky, M.; Warren, C. E. Glycoprotein glycosylation and cancer progression. Biochim. Biophys. Acta 1999, 1473, 21-34.

(4) Olden, K.; Breton, P.; Grzegorzewski, K.; Yasuda, Y.; Gause, B. L.; Oredipe, O. A.; Newton, S. A.; White, S. L. The potential importance of swainsonine in therapy for cancers and immunology. Pharmacol. Ther. 1991, 50, 285-290.

(5) van den Elsen, J. M.; Kuntz, D. A.; Rose, D. R. Structure of Golgi alpha-mannosidase II: a target for inhibition of growth and metastasis of cancer cells. EMBO J. 2001, 20, 3008-3017.

(6) Asano, N. Gylcosidase inhibitors: update and perspectives on practical use. Glycobiology 2003, 13, 93R-104R.

(7) Colegate, S. M.; Dorling, P. R.; Huxtable, C. R. A spectroscopic investigation of swainsonine: an $\alpha$-mannosidase inhibitor isolated from Swaisona canescens. Aust. J. Chem. 1979, 32, 22572264. 
(8) Goss, P. E.; Reid, C. L.; Bailey, D.; Dennis, J. W. Phase IB clinical trials of the oligosaccharide processing inhibitor swainsonine in patients with advanced malignancies. Clin. Cancer Res. 1997 3, 1077-1086.

(9) Kino, T.; Inamura, N.; Nakahara, H.; Kiyoto, K.; Goto, T.; Terano, H.; Kohsaka, M.; Aoki, H.; Imanaka, H. Effect of swainsonine on mouse immunodeficient system and experimental murine tumor. J. Antibiot. 1985, 38, 936-940.

(10) Pearson, W. H.; Guo, L. Synthesis and mannosidase inhibitory activity of 3-benzyloxymethyl analogs of swainsonine. Tetrahedron Lett. 2001, 42, 8267-8271.

(11) Dennis, J. W.; White, S. L.; Freer, A. M.; Dime, D. Carbonoyloxy analogs of the anti-metastatic drug swainsonine. Biochem. Pharmacol. 1993, 46, 1459-1466.

(12) Pearson, W. H.; Hembre, E. J. Synthesis and mannosidase inhibitory activity of 6 - and 7-substituted analogs of swaisonine. Tetrahedron Lett. 2001, 42, 8273-8276.

(13) Popowycz, F.; Gerber-Lemaire, S.; Rodriguez-García, E.; Schütz, C.; Vogel, P. Synthesis and $\alpha$-Mannosidase Inhibitory Evaluation of (2R- and 2S,3R,4S)-2-(Aminomethyl) pyrrolidine-3,4-diol Derivatives. Helv. Chim. Acta 2003, 86, 1914-1948.

(14) Carmona-Asenjo, A. T.; Popowycz, F.; Gerber-Lemaire, S.; Rodriguez-García, E.; Robina, I.; Vogel, P. Synthesis and Glycosidases Inhibitory Activities of 2-(aminoalkyl) pyrrolidine-3,4diol Derivatives. Bioorg. Med. Chem. 2003, 11, 4897-4911.

(15) Popowycz, F.; Gerber-Lemaire, S.; Schütz, C.; Vogel, P. Syntheses and glycosidase inhibitory activities of 2-(aminomethyl)-5 (hydroxymethyl)pyrrolidine-3,4-diol derivatives. Helv. Chim. Acta 2004, 87, 800-810.

(16) Egidy, G.; Peduto Eberl, L.; Valdenaire, O.; Irmler, M.; Majdi, R.; Diserens, A..C.; Fontana, A.; Janzer, R. C.; Pinet, F.; Juillerat-Jeanneret, L. The endothelin system in human glioblastoma. Lab. Invest. 2000, 80, 1681-1689.

(17) Berger, Y.; Dehmlow, H.; Blum-Kaelin, D.; Kitas, E. A.; Löffler B. M.; Aebi, J.; Juillerat-Jeanneret, L. Endothelin-convertingenzyme-1 inhibition and growth of human glioblastoma cells. $J$ Med. Chem.in press.

(18) Juillerat-Jeanneret, L.; Célérier, J.; Chapuis Bernasconi, C.; Nguyen, G.; Wostl, W.; Maerki, H. P.; Janzer, R. C.; Corvol, P.;
Gasc, J. M. Renin and angiotensinogen expression and function in growth and apoptosis of human glioblastoma. Br. J. Cancer 2004, 90, 1059-1068.

(19) Hanessian, S.; Zhan, L.; Bovey, R.; Saavedra, O. M.; JuilleratJeanneret, L. Functionalized glycomers as growth inhibitors and inducers of apoptosis in human glioblastoma cells. J. Med. Chem. 2003, 46, 3600-3611.

(20) Fleet, G. W. J.; Son, J. C. Polyhydroxylated pyrrolidiens from sugar lactones: synthesis of 1,4-dideoxy-1,4-imino-D-glucitol from D-galactonolactone and syntheses of 1,4-dideoxy-1,4-imino-Dallitol, 1,4-dideoxy-1,4-imino-D-ribitol, and (2S,3R,4S)-3,4-dihydroxypyrrolidine from D-gulonolactone. Tetrahedron 1988, 9 , 2637-2647.

(21) Lemaire-Audoire, S.; Savignac, M.; Genet, J.-P. Selective deprotection of allyl amines using palladium. Tetrahedron Lett. 1995 , $36,1267-1270$.

(22) Brandi, A. Cicchi, S.; Cordero, F. M.; Frignoli, B.; Goti, A. Picasso, S.; Vogel, P. Assignment of the absolute configuration of natural Lentiginosine by synthesis and enzymatic assays of optically pure (+) and (-)-enantiomers. J. Org. Chem. 1995, 60, 6806.

(23) Howard, S.; Braun, C.; McCarter, J.; Moremen, K. W.; Liao, Y.F.; Withers, S. G. Human lysosomal and jack bean $\alpha$-mannosidases are retaining glycosidases. Biochem. Biophys. Res. Commun. 1997, 238, 896-898.

(24) Berger, Y.; Greppi, A.; Siri, O.; Neier, R.; Juillerat-Jeanneret, L. Ethylene glycol and amino acid derivatives of 5-aminolevulinic acid as new photosensitizing precursors of protoporphyrin IX in cells. J. Med. Chem. 2000, 43, 4738-4746.

(25) Diserens, A. C.; de Tribolet, N.; Martin-Achard, G.; Gaide, A C.; Schnegg, J. F.; Carrel, S. Characterization of an established human malignant glioma cell line. Acta Neuropathol. 1981, 53 $21-28$.

(26) Bullani, R. R.; Wehrli, P.; Viard-Leveugle, I.; Rimoldi, D.; Cerottini, J. C.; Saurat, J. H.; Tschopp, J.; French, L. E. Frequent downregulation of Fas (CD95) expression and function in melanoma. Melanoma Res. 2002, 12, 263-270.

JM0409019 